\title{
La justicia excepcional en la primera mitad del XIX cubano: orden público y gobierno militar de los territorios coloniales
}

\author{
Alina Castellanos Rubio* \\ Université Bordeaux Montaigne (UBM) \\ Bordeaux - Francia \\ Universidad del País Vasco (UPV) \\ Bilbao - España
}

El presente artículo analiza el funcionamiento y trascendencia de un tribunal especial militar actuante en Cuba durante la primera mitad del siglo XIX, la Comisión Militar ejecutiva y permanente (1825-1856). Dicho tribunal conoció de manera exclusiva de los delitos de carácter político durante los años de su actuación, aunque la mayor parte de su trabajo cotidiano en términos cuantitativos estuvo dirigido al control de la criminalidad, el bandolerismo y el mundo esclavo. Su valor como dispositivo de intervención ejecutiva, en tanto escapaba a las formas jurisprudenciales tradicionales de gestión del orden, hizo que deviniese la principal institución de orden público en la colonia durante la primera mitad del siglo. Gracias a él, la regularización de la especialidad, del gobierno de las islas "como en estado de sitio" fue ordinaria, en el sentido de cotidiana, normalizada y sostenida.

\section{Palabras claves}

Comisión militar, vía extraordinaria, orden público, Cuba, siglo XIX.

* Doctoranda de Études ibériques et ibéro-américaines de la Universidad Bordeaux Montaigne (UBM), Francia, en cotutela con el programa de doctorado Europa y el mundo atlántico: poder, cultura y sociedad, de la Universidad del País Vasco (UPV), España. El proyecto de tesis beneficia de una ayuda del Estado francés gestionada por la Agence Nationale de la Recherche a título del programa Investissements d'avenir Initiative d'excellence IdEx Bordeaux, con referencia ANR10-IDEX-03-02. E-mail: alinacr24@gmail.com. 


\section{Resuimo}

O presente artigo analisa o funcionamento e transcendência de um tribunal especial militar atuante em Cuba durante a primeira metade do século XIX, a Comissão militar executiva e permanente (1825-1856). O referido tribunal conheceu de maneira exclusiva os delitos de caráter político durante os anos de sua atuação, embora a maior parte de seu trabalho cotidiano em termos quantitativos esteve direcionado ao controle da criminalidade, da bandidagem e do mundo escravo. Seu valor como dispositivo de intervenção executiva, enquanto se desviava das formas jurisprudenciais tradicionais de gestão da ordem, fez com que se tornasse a principal instituição de ordem pública na colônia durante a primeira metade do século. Graças a ele, a regularização da especialidade, do governo de ilhas "como em estado de sítio", foi ordinária, no sentido de cotidiana, normalizada e sustentada.

\section{Palavras-chave}

Comissão militar, via extraordinária, ordem pública, Cuba, século XIX 


\section{Prólogo}

\section{La excepcionalidad americana}

Considerados como "Reinos y Señoríos de Indias", los espacios americanos fueron incorporados jurídica e institucionalmente al entramado de gobierno jurisdiccional de la monarquía católica durante el proceso de colonización española (que puede considerarse pues como de territorialización del poder real soberano de Castilla ${ }^{1}$ ), sin establecerse a priori y de manera formal criterios de diferenciación jurídica-política para los nuevos reinos ultramarinos. El desarrollo jurídico-institucional exclusivamente indiano, como la creación de un Consejo de Indias por ejemplo o la aparición de sucesivas recopilaciones con disposiciones legales particulares para los vastos dominios americanos, respondió, como bien sintetiza C. Garriga, a "(...) la notable quidditas indiana, pero no sería la expresión jurídico-política de su consideración como territorio separado dentro de la Corona de Castilla."2

La excepcionalidad jurídica americana fue asentada formalmente durante el reinado de Carlos IV, con la imposición de criterios de gobierno distintos en virtud de la lógica de la "necessitas", el argumento que permitía alterar el orden de manera legítima en el universo conceptual del ius commune durante el Antiguo Régimen. ${ }^{3}$ Si durante los tres primeros siglos de dominación continental una "peculiaridad americana" emergió en determinadas prácticas institucionales y legislativas (que no corresponde analizar en estas breves líneas), "adaptadas" a una clara consciencia de la misma, el efectivo proceso que llevó a la especialización indiana comenzó a hacerse visible a partir de 1763, con el

1 GARRIGA ACOSTA, Carlos. Patrias criollas, plazas militares: sobre la América de Carlos IV. Horizontes y Convergencias. Lecturas Históricas y Antropológicas sobre el Derecho, 2009, apartado 2.2. s/p.

2 Ibídem., apartado 2.3. s/p. La pregunta que puede plantearse el lector relacionada con el derecho llamado "indiano", que nunca llegó a constituir "orden jurídico exclusivo o propio para las Indias", queda también explicada en este texto, que remite a su vez a los trabajos de Javier BARRIENTOS GRANDÓN y Víctor TAU ANZOÁTEGUI sobre el tema.

3 LACCHÉ, Luigi. Ordo non servatus. Anomalie processuali, giustizia militare e specialia in Antico Regime. Studi Storici, 29-2, 1988. p. 361-384. 
establecimiento de una política defensiva continental y la consecuente (re)calificación de los territorios indianos en "plazas militares". A través de este mecanismo no solo se intentó frenar el avance inglés sobre el continente tras la Guerra de Siete Años, sino también contrarrestar el proceso de reivindicación criolla al autogobierno y la constitución de un espacio político propio (y separado). Esa "nueva" concepción colonial de las Indias, implícita en las medidas paulatinamente adoptadas y nunca expresamente afirmada, se intentó posponer en las reclamaciones del discurso criollo por la reivindicación de sus derechos en Cádiz, pero todo lo que se consiguió en ese sentido con la Constitución de 1812 quedó derogado después en el artículo adicional primero sobre el sistema de leyes especiales para Ultramar de la Constitución de 1837.

Por otro lado, una Real Orden de 12 de enero de 1835 introdujo en España el "estado de sitio", es decir, el sometimiento de un determinado territorio a la autoridad militar. La Real Orden de 1835 se apoyó en las Ordenanzas de ejército de 1768 para fundamentar el poder de los Capitanes Generales sobre un territorio - a quienes se les otorgaban "en determinados supuestos y en el ámbito castrense, un poder normativo ilimitado referido en particular a la legislación penal"-, sin precisarse en realidad sus atribuciones ni ser mucho más explícita en ese sentido. ${ }^{4}$ Esta práctica sin embargo ya era usual en Cuba, donde se habían concedido facultades omnímodas a dichas figuras una década antes, justamente cuando la crisis imperial de la Monarquía ibérica se confirmó definitiva. ${ }^{5}$ Una de las expresiones más visibles de ese poder militar decimonónico (en su sentido de típicamente decimonónico) lo constituyó la Comisión militar ejecutiva y permanente de la Isla de Cuba (18251856), tribunal excepcional que constituyó experimento de larga du-

4 GRUZ VILLALÓN, Pedro. El estado de sitio y la Constitución. La constitucionalización de la protección extraordinaria del Estado (1789-1878). Madrid: Centro de Estudios Constitucionales, 1980. pp. 328-330.

5 Un proceso que había comenzado ya durante el gobierno de Ricla (1763-1765) y que continuaría con amplias trascendencias como veremos más adelante, en una línea que J. M. Fradera ha calificado de tendencia centralista de construcción de "un pretorianismo político-militar fuerte". FRADERA, Josep M. La Nación Imperial (1750-1918), Barcelona: Edhasa, 2015. V. II, p. 755. 
ración en el territorio antillano, devenido, tras la crisis revolucionaria, la posesión más preciada de la Corona. ${ }^{6}$ A su constitución, actuación y mecanismos de legitimación están dedicadas las siguientes páginas.

\section{¿Por qué comisiones militares?}

Por Real Instrucción de 29 de junio de 1784 expedida para la persecución de malhechores y contrabandistas en todo el reyno, se dispuso de una serie de compañías militares para garantizar la "seguridad pública" - fenómeno que se inicia con la Guerra de Sucesión y con la creación a partir de 1761 de compañías para este fin. Planteaba la movilización de tropas en tiempo de paz para la persecución y aprehensión de "ladrones, contrabandistas, desertores, vagos y toda clase de malhechores". Se crearon en virtud de esa instrucción varias comisiones militares integradas "por soldados y contrabandistas arrepentidos", tratándose en estos casos de comisiones militares puntualmente localizadas y asociadas a la personalidad militar que las dirigía. Se creaba así en España un antecedente concreto para los juicios militares a civiles, ratificado por Real Orden de 30 de marzo de $1802 .^{7}$

La intervención judicial militar no es sin embargo una innovación dentro del corpus jurídico de Antiguo Régimen, como ha sido señalado por la historiografia italiana. El procedimiento "ad modum belli, de facto, ad horas" fue contemplado por los juristas tradicionales como una sana alternativa ante la evidencia de crímenes calificados de "atroces", tales como los delitos de lesa-majestad, y dio origen a una dúplice capacidad de respuesta del orden jurídico tradicional desarrollada a partir del siglo XVI a través del binomio ordinario / extraordinario. ${ }^{8}$

${ }_{6}$ FRADERA, Josep M. De la periferia al centro. (Cuba, Puerto Rico y Filipinas en la crisis del Imperio español). Anuario de Estudios Americanos, vol. 61, nº 1, 30 Juin 2004, pp. 161-199.

7 MELONJIMÉNEZ, Miguel Ángel. Una cuestión de Estado. La persecución del contrabando durante los reinados de Carlos III y Carlos IV. Mélanges de la Casa de Velázquez, 39-2, 2009. pp. 83-103.

${ }^{8}$ La aplicación de la lógica del "ordo non servatus", o sea, el receso de las reglas del derecho ordinario u "ordo procedendi", se hacía efectiva en virtud de la "reipublicae salus" y se acompañaba de una fuerte energía punitiva: "(..) el autor de un crimen atroz, moral y socialmente aborrecible, "hostes omnium", 
Esta dúplice capacidad de respuesta del orden tradicional debe ser entendida a cabalidad porque en ello radica la diferencia fundamental con nuestro actual sistema de excepcionalidad. En el universo conceptual del ius comunne lo extraordinario es visto como "un remedio necesario" que sirve para suplir el procedimiento ordinario ahí donde este resulta insuficiente, y, aunque exprese una anomalía, no implica un estado de "anomia": fuera de lo ordinario sí, pero no por ello externo al orden jurídico. ${ }^{9}$ Ello quiere decir que lo excepcional es considerado en un plano constitutivo del propio ordenamiento jurídico, que se configura así en la convergencia dialéctica entre ordinario y extraordinario; a diferencia de la concepción propia de los siglos contemporáneos donde se pone en relación la excepcionalidad con la emergencia, excluyéndola por tanto del campo del proceso constitutivo del orden jurídico. En síntesis, en el universo tradicionalista - esto es algo que debe anotarse ahora porque será importante luego en el argumento de este artículo"el espacio de la excepción está pensado para que opere siempre en el lecho legitimante de la iurisdictio" 10 , abarcando toda forma de "desvío" de las reglas del derecho antes que su suspensión. Su traducción concreta era de tipo "técnica", sobre todo en provecho de la acción procesal (inquisitoria). Así, la paulatina ampliación del concepto de enormitas hizo posible el establecimiento desde el siglo XVIII de tribunales militares en la Península para la persecución de contrabandistas y malhechores, por lo que significaban de simplificación e inmediatez del proceso y ejemplaridad del castigo.

Pero si las comisiones militares del XVIII se habían creado como solicitud del gobierno económico de los territorios (para hacer frente al contrabando fundamentalmente), la apertura de estos tribunales como dispositivo inquisitorial a partir de 1824 fue fundamentado dentro de

perjudicial, en la representación ideológica, al entero "ordo societatis", no puede sino sufrir una pena "bárbara"». LACCHÉ, Luigi. Op. Cit. p. 365. La traducción me pertenece.

9 MECCARELLI, Massimo. Paradigmi dell'eccezione nella parabola della modernità penale. Una prospettiva storico-giuridica. Quaderni storici, no 2, 2009, pp. 493-522.

${ }^{10}$ Ibidem, p. 497. La traducción me pertenece. 
una retórica netamente política, amparada en el mantenimiento del orden. ${ }^{11}$ El establecimiento de los tribunales marciales por Real Orden de 13 de enero de 1824, posteriormente reproducida en otra de 18 de marzo de 1834, se consideró una reformulación a efectos institucionales de la llamada "ley de orden público" de 17 de abril de 1821.12 De hecho, las reiteraciones de la ley de 1821 a lo largo del siglo en el territorio peninsular se acompañaron de disposiciones sobre la intervención de comisiones militares para juzgar en exclusivo los delitos por ella señalados, ${ }^{13}$ aunque otras veces las segundas aparecieron sin pasar por una publicación de la primera. En la Península, la actuación de estos tribunales comporta un matiz de intermitencia, aunque hay territorios como Cataluña donde, si no estables, resultaron muy frecuentes. ${ }^{14}$ Pero en general fueron reactivadas, aun luego de su supresión en 1834,

${ }^{11}$ La preferencia por un instrumento militar fiel a la Corona al que encargarle el control social durante la coyuntura represiva pos-constitucional se muestra en el decreto de creación de la Superintendencia General de Policía del mismo día 13 de enero de 1824, el cual regulaba su actuación "ínterin se establece el Cuerpo militar destinado particularmente a la seguridad de los pueblos y de los caminos" (artículo 15); fórmula repetida casi exactamente igual en el Reglamento de Policía de Madrid de febrero de 1825 (artículo 167: "Interin se establece el Cuerpo militar destinado particularmente al servicio de la Policía..."). Cit. por: LORENTE SARIÑENA, Marta; MARTÍNEZ PÉREZ, Fernando. Orden público y control del territorio en España (1822-1845): de la Superintendencia general de policía a la Guardia civil. Revista jurídica Universidad Autónoma de Madrid, n 19, 2009, pp. 195-210, particularmente p. 202.

${ }^{12}$ CARAVANTES, José Vicente. Tratado de los procedimientos en los Juzgados militares. Madrid: Imprenta y librería de Gaspar y Roig, editores, 1853. p. 300.

${ }^{13}$ Así, por ejemplo, a partir del restablecimiento de la ley de abril de 1821 en 1836, se dictaron las Reales Ordenes de 26 de septiembre de 1844 (sobre juicios a malhechores capturados por partidas de seguridad), de 23 de mayo de 1850 (sobre la obligatoriedad de la autoridad militar para la persecución y juicio de salteadores y ladrones), y la de 30 de julio de 1850 (sobre el traspaso de este tipo de causas a la autoridad militar por parte de la civil). Ibidem. p. 301.

${ }^{14}$ El reforzamiento de la autoridad militar en Cataluña sigue una cronología relativamente paralela a la cubana. Se inicia en 1835 cuando el Capitán General Mina inaugura una práctica de proclamación del estado de guerra mediante bando de 19 de noviembre de 1835, que fue mantenido hasta el 5 de noviembre de 1836. Desde entonces la reiteración en la proclamación del estado de sitio en Cataluña / Barcelona se sucedió de forma ininterrumpida: 14/1-18/4/1837; 4/9/183724/7/1839; 1841; 1842-1843; y desde 1844 a 1854 de forma permanente. RISQUES CORBEILLA, Manel. La militarización del control político sobre el territorio. Barcelona, Gobierno civil y orden público en la primera mitad del siglo XIX. (2014, Inédito). 
con las declaraciones temporales de estados de sitio. En Cuba sin embargo revistió una particular importancia la creación de una Comisión militar ejecutiva y permanente un año después de decretarse su creación en España. Resultado de la intención de orden del gobierno de Fernando VII, y a pesar de no sobrevivir bien a la victoria del liberalismo en la Península, en Cuba la Comisión militar resultó ser un experimento de larga duración, pues constituyó la principal institución de orden público entre 1825 y 1856 en la Isla, con una represión rigurosa y sistemática del desorden social -y no solo político como se puede inferir de su cometido original-, a lo largo de todo el período.

\section{La Comisión militar ejecutiva y permanente de la Isla de Cuba (1825-1856): funcionamiento de un tribunal excepcional}

La alternativa de un tribunal militar para el control social no fue solo parte de la política represiva fernandina, sino algo ya barajado por el mando supremo insular y con lo que estuvieron conformes varias de las mayores fortunas del occidente cubano. ${ }^{15}$ Aunque su establecimiento formó parte de la estrategia militar del gobierno de Fernando VII luego de 1823 para la defensa del territorio cubano del enemigo exterior americano, con la permanencia prolongada del tribunal cubano se evidenció la conciencia que se tenía de los aires reformistas que se respiraban en la Isla, lo que venía a sumarse al antiguo miedo de los propietarios cubanos a un levantamiento esclavo como el de la colonia francesa de Saint Dominique. En este contexto se estableció en La Ha-

\footnotetext{
${ }^{15}$ Ya en enero de 1808 José de Balby enviaba una propuesta al Ayuntamiento de La Habana, titulada "Representación de un vecino de Santiago [de las Vegas] dirigida al bien general y conservación de la Colonia", en la que proponía la creación de milicias "que controlen a los esclavos en sus movimientos y defiendan las propiedades de la gente forajida", y, más allá de la vigilancia esclava, su propuesta contemplaba que "los casos de asesinato, atentado, incendio, robo y desorden ya sean cometidos por los esclavos, ya sean cometidos por libres fascinerosos se juzgarán por Consejo de Guerra". ACTAS Capitulares del Ayuntamiento de La Habana. Libro 62, Acta de 15 de enero de 1808. Museo Histórico de la Oficina del Historiador. La Habana, Cuba.
} 
bana el tribunal excepcional, que a su vez contribuyó al reforzamiento marcial del poder colonial del que hemos dado cuenta antes.

La apertura efectiva del tribunal se produjo en julio del propio año 1824. Según la Real Orden de creación de las comisiones militares los Capitanes Generales eran los encargados de la designación de sus miembros entre los oficiales de ejército, como máxima autoridad del distrito militar. El tribunal quedaba compuesto por un Presidente, seis Vocales que actuaban como jueces, consultados por un Asesor sin voto para las sentencias, cuatro Fiscales y cuatro Secretarios, ${ }^{16}$ con una estructura deudora de las establecidas por las Ordenanzas militares para los consejos de guerra. Pero entre estos y las comisiones se produjo la mayúscula y trascendental diferencia de que en el caso de las segundas los nombramientos de los vocales, fiscales y secretarios se hicieron con carácter de permanente. ${ }^{17}$

La disposición del Capitán General Francisco Dionisio Vives de 4 de marzo de 1824 para la creación de la Comisión militar cubana se escudó en los temores que se vivían a raíz de las revoluciones continentales. Advertía el Capitán General desde el inicio mismo de su comunicación pública que el tribunal se constituía en virtud de la "tranquilidad y seguridad" de la Isla y para "preservar de los horrores y las ruinas que traen consigo las inquietudes que se han experimentado en sus dominios de América". ${ }^{18}$ Formado por personas "de la entera confianza de S.E", la presidencia de la Comisión habanera recayó durante su primera etapa

${ }^{16}$ Los secretarios se designaron de entre la clase de tropa hasta 1831, y con posterioridad de entre los oficiales, aunque no necesariamente capitanes, según Real Orden de 3 de noviembre de ese año.

${ }^{17}$ Se ratificó en Real Orden de 25 de junio de 1840. Este elemento solo fue revisado durante el gobierno del Capitán General Jerónimo Valdés cuando por circular de 7 de abril de 1841 se estableció la cesación de los Vocales permanentes de la Comisión Militar y la designación casuística a partir de entonces de oficiales de la plaza de La Habana para desempeñar dicha función, convocados nominalmente por la Secretaría militar la víspera de la celebración de los consejos de guerra. Quedó confirmado en Real Orden de 30 de abril de 1852. Los Fiscales y Secretarios permanecieron con empleos permanentes, que generalmente ocupaban durante largos años. Archivo Nacional de Cuba (en adelante ANC). Fondo Comisión Militar, leg. 1, exp. 1 y leg. 133 exp. 1.

${ }^{18}$ Orden del E. S. Gobernador y Capitán General D. Francisco Dionisio Vives de 5 de marzo de 1825. ANC. Fondo Comisión Militar, leg. 1 exp. 1. 
(1825-1836) en José María Cadaval, ${ }^{19}$ militar ya probado como represor social; y como Asesor fue nombrado un Oidor honorario de la Audiencia Territorial de Puerto Príncipe, José Ildefonso Suárez, quien constituyó durante dos décadas hombre clave del poder del Capitán General en Cuba. ${ }^{20}$

Con el transcurso del tiempo se varió la organización original y competencias del tribunal según voluntad de sus presidentes y no por disposiciones de Madrid, ${ }^{21}$ un elemento que no sorprende dado el carácter ejecutivo del tribunal y su dependencia exclusiva del mando supremo en la Isla, que contaba con total aprobación del gobierno: "concedida como le está cuanta autoridad es necesaria para sostener el buen orden y labrar la felicidad de los habitantes de esa Isla, es consiguiente que las providencias

${ }^{19}$ Aunque en la disposición primera de Vives se nombró al Brigadier Luis Michelena, este no llegó a ocupar la presidencia del tribunal. Cadaval era en el momento de su nombramiento Teniente Rey de la plaza de La Habana y II Cabo de la Isla, con grado de Brigadier. De origen peninsular, desarrolló su carrera militar en la capital cubana casado con Luisa Chacón y Calvo. Su desempeño y ascensos militares se debieron a represiones de carácter político durante los gobiernos de los Capitanes Generales Mahi (1821-22), Kindelán (1822-23) y Vives (1823-32), sobre todo frente a la denominada Conspiración de Soles y Rayos de Bolívar. En 1834 llegó a desempeñar interinamente la vacante de la Capitanía General.

${ }^{20}$ José Ildefonso Suárez era a la vez Asesor primero del gobierno y de la Comisión militar, además de Oidor honorario de la Audiencia. Con peso ya durante los gobiernos de Mahi, Kindelán y Vives [Archivo General de Indias (en adelante AGI), Indiferente, 248, N.179], con Ricafort (1832-34) y Tacón (1834-38) fue la persona que fundamentó jurisprudencialmente las decisiones y órdenes de la máxima autoridad insular, llegando a constituir mano derecha del Marqués de la Unión de Cuba, como se evidenció cuando los sucesos de la declaración constitucional del General Manuel Lorenzo en Santiago de Cuba en 1836 [Manifiesto del general Don Manuel Lorenzo a la nación española. Cádiz: Campe, 1837]. Su carrera política terminó de forma polémica: en 1838 fue expuesto públicamente por venalidad y corrupción, lo que condujo a su inhabilitación definitiva por Real Orden de 25 de diciembre de 1839; casualmente luego del fin del mandato de Tacón.

${ }^{21}$ Por ejemplo, a partir de la década de 1840 los asesores dejaron de ser civiles, recayendo en los asesores y fiscales de otros juzgados de vestimenta marcial de la ciudad; una disposición que no se verificaría por Real Orden hasta el 9 de julio de 1852. LLAVERÍAS, Joaquín. La Comisión militar ejecutiva y permanente de la Isla de Cuba. Academia de Historia de Cuba. La Habana: Imprenta El Siglo XX, 1929. p. 16. 
que V.E. manifiesta estarán dictadas con pleno conocimiento de antecedentes y celo que exigen el bien público y tanto le distingue". ${ }^{22}$

Desde el primer momento quedó claro que la Comisión juzgaría en exclusivo por los delitos que mencionaba la Real Orden de marzo de 1824, es decir, a sediciosos, conspiradores, ladrones, malhechores, y en general todo el espacio ambiguo referido a delitos políticos ${ }^{23}$, sin importar la autoridad que ejecutase la aprehensión -lo mismo la tropa, la justicia ordinaria o las autoridades de policía- ${ }^{24}$ ni el propio texto de la Real Orden que en su artículo $17^{\circ}$ establecía límites a la actuación del tribunal. ${ }^{25}$ Este proceder se justificó en que "[s]iendo militar la organización gubernativa y administrativa de la isla, es indudable que en la casi totalidad de las casos entendería el Consejo de guerra... "926 al disponerse por un militar la orden de captura o persecución de los reos. Y, efectivamente, el grueso del entramado institucional gubernativo cubano estaba en

${ }^{22}$ Carta aprobando las disposiciones de la capitanía general sobre reducción de atribuciones de la Comisión militar de la Isla de Cuba. 1841. ANC. Fondo Reales Ordenes y Cédulas, leg. 123, exp. 119.

${ }^{23}$ La Disposición de Vives sintetizaba de manera ambigua, como era usual en la tradición de Antiguo Régimen, las causas competentes al tribunal, lo que condujo a una amplia libertad de interpretación de las cláusulas: “...que entienda y juzgue los delitos de los declarados con armas, papeles, pasquines, o con hechos de cualquiera clase, enemigos de los legítimos derechos del trono, o partidarios de la constitución, publicada en Cádiz (...) de los que en parages [sic] públicos hablen contra la soberanía de S.M., o en favor de la abolida constitución, de los que seduzcan, o procuren seducir a otros con el objeto de formar algún partido, y de los que promuevan alborotos que alteren la tranquilidad pública, cualquiera que sea su naturaleza, o el pretexto de que se valgan para ello, extendiéndose además la autoridad de la misma Comisión conocer de las causas que se formen a los ladrones, y malhechores que en los caminos y casas de campo sean aprehendidos por cualquier tropa..." ANC. Fondo Comisión Militar, leg. 1, exp. 1.

${ }^{24}$ Respuesta del Auditor de Guerra a una consulta sobre la aprehensión de ladrones y malhechores, en marzo de 1825: “... la duda que pudiera haber sobre ser precisa circunstancia la de ser aprehendidos los delincuentes por tropa, y no hay más que dos extremos, o prende la tropa y su Comandante entrega al Presidente de la Comisión, o prende la fusticia en los caminos y casas de campo al ladrón y malhechor, y en este caso debe entregarlo con la sumaria al Presidente de la Comisión por ser este uno de dichos criminales sujetos al juicio de aquella." Ibidem.

25 "Art. 17". Contra los otros malhechores o reos que no fuesen de dichas clases, ni cómplices, se abstendrá de proceder la Comisión militar ejecutiva permanente, quedando sujetos a las justicias a quienes corresponda el conocimiento de sus causas y delitos (...)". Real Decreto de 13 de enero del año de 1824. Ibidem.

${ }^{26}$ Voto consultivo del Real Acuerdo sobre la supresión de la Comisión militar, 10 de julio de 1855 . ANC. Fondo Comisión militar, leg. 120, exp. 6. 
manos de militares. Ello generó una práctica colonial de procesamiento en este tipo de tribunales marciales de los delitos de carácter político que se extendería hasta finales de siglo, aun cuando el equipamiento institucional judicial cubano cambió de organización y vestimenta a partir de los años 1850.

Rápidamente se incluyó entre las competencias de la Comisión cubana las sublevaciones de esclavos, amparado en el supuesto tradicional del procedimiento simplificado por la gravedad del crimen y la necesaria ejemplaridad del castigo. El tribunal militar procedía sumariamente en las averiguaciones y hacía "justicia ejemplar" con los líderes.

En general, la sustanciación de las causas se hacía con arreglo a las Ordenanzas militares ${ }^{27}$, pero se intentaba sintetizar los procedimientos. Por ejemplo, según la disposición de 1824 la fórmula de los careos podía omitirse por considerarse dilatoria, a menos que los solicitase la defensa, ${ }^{28}$ aunque fue verificada con frecuencia durante los procesos en Comisión según los expedientes consultados. Los careos constituían el momento casi exclusivo de defensa del reo frente a las acusaciones durante los juicios militares, ya que su comparecencia en el consejo de guerra no era requisito indispensable. En las prácticas de las comisiones militares se dejaba en manos exclusivamente de los oficiales procuradores la defensa, lo que resultaba poco fiable dada la obligatoria vestimenta militar y el nombramiento de oficio, y consecuentemente aleatorio, de este personaje. ${ }^{29}$ La opinión más extendida y reiterada a

${ }^{27}$ Según las Reales Ordenanzas el procedimiento en juicios militares se practicaba a partir de: Sumaria o primeras averiguaciones, Plenaria (declaración de testigos, deposición del reo, ratificación de testigos y peritos, careo y dictamen fiscal), Consejo de Guerra ordinario y ejecución de la sentencia. ORDENANZAS de S.M. para el régimen disciplinario de sus ejércitos. 1768. Madrid: en la Imprenta Real, 1815. Tomo Tercero, Tratado VIII, "De las materias de Justicia".

${ }^{28}$ Esto ya se había formulado con anterioridad en la Real Orden de 26 de julio de 1803 para abreviar los procesos de juicios militares contra ciudadanos comunes. CARAVANTES, José Vicente. Op. Cit. p. 298.

${ }^{29}$ Un ejemplo de una situación "particular" puede ilustrar este hecho: en septiembre de 1829 el Presidente del tribunal se quejó al Capitán General de "la enfebrecida actitud de un Teniente en calidad de procurador durante un consejo de guerra", pidiendo su castigo ya que "se ha separado notablemente del mérito del proceso en su defensa contra lo prevenido en las Reales Ordenanzas llevando a tal punto su 
lo largo de los años a partir de esa manera de proceder era que en los juicios en Comisión el reo carecía de medios de defensa, lo que contribuyó sin dudas a su proyección represiva. A ello se suma el hecho de que la designación del oficial defensor se hacía incontinenti en el momento de tomarse las confesiones de los reos (es decir, luego de ratificados los testigos y antes del dictamen fiscal), y solo entonces el procurador lego podía trazar una estrategia defensiva, sin mediar consejo legal alguno por parte de civiles. Los alegatos eran presentados durante los juicios o consejos de guerra una vez dictaminada la causa por el promotor fiscal. En ocasiones el consejo podía hacer pasar a los reos - una vez oídos fiscales y procuradores - para interrogarlos "sobre cuanto juzgó conveniente", y los acusados exponer "todo lo que creyeron oportuno a su descargo", pero esta práctica no puede considerarse generalizada. ${ }^{30}$

En cuanto a las penas, según el artículo décimo de la Real Orden de 13 de enero de 1824 estas debían imponerse de acuerdo al decreto de 4 de mayo de $1814,{ }^{31}$ pero en la práctica cotidiana del tribunal las sentencias fueron arregladas a las recopilaciones legislativas al uso en

acaloramiento que todavía al despejarse la sala del Consejo tomó de nuevo la palabra expresando con mucha audacia que estimando su defensa no fundada en sofismas esperaba que la meditase bien aquel Tribunaly aun posteriormente he sabido que en el zaguán de la casa tuvo atrevimiento para decir que aquellos infelices iban a ser sacrificados, lo que ha vociferado en otros muchos puntos. Y como semejante conducta no es de tolerar en un oficial que sabe o debe saber el respeto y consideración que se debe a un Consejo de Guerra y lo que perjudican en la opinión pública semejantes murmuraciones cumple con el acuerdo del Tribunal para que V.E. se sirva tomar las providencias que juzgue acertadas." AGI, Papeles de Cuba, leg. 2085. El resaltado me pertenece.

${ }^{30}$ ANC. Fondo Comisión militar, leg. 133, exp. 1. Lo citado corresponde a un caso del año 1851 y a una situación bastante particular, la de no comparecencia del defensor en el momento de realizarse el Consejo de guerra.

${ }^{31}$ DECRETOde Valencia. Madrid: Gaceta Extraordinaria de Madrid del Jueves 12 de Mayo de 1814, que sobre las penas establece: “(...) $Y$ como el que quisiese sostenerlos, y contradijere esta mi real declaración, tomada con dicho acuerdo y voluntad, atentaría contra las prerrogativas de mi soberanía y la felicidad de la nación, y causaría turbación y desasosiego en mis reinos, declaro reo de lesa Majestad a quien tal osare o intentare, y que como a tal se le imponga la pena de la vida, ora lo ejecute de hecho, ora por escrito o de palabra, moviendo o incitando, o de cualquier modo exhortando y persuadiendo a que se guarden y observen dicha constitución y decretos. (...).” Agencia Estatal Boletín Oficial del Estado (BOE). Referencia BOE-A-1814-282. Disponible en: Http:// www.boe.es/datos/pdfs/BOE//1814/070/A00515-00521.pdf. Acceso en: 5 de enero de 2017. 
los juzgados ordinarios, con preferencia las Partidas y la Novísima Recopilación, según las pruebas de derecho aportadas por los fiscales actuantes. Sobre este elemento de las penas, se aprecia una sistematicidad en las sentencias dictadas en los consejos de guerra, que mantuvieron una coherencia a lo largo de los años en la correspondencia delito / pena.

En este sentido, un dato estadístico arroja luces: entre 1825 y 1836 para un total de 162 procesos enumerados, las penas de presidio (tanto en la Isla como en África / Ceuta), destierro, deportación o extrañamiento y, en menor medida, las capitales, fueron casi las únicas que se aplicaron en la Comisión - a ellas se suman contadas condenas a obras públicas y servicio de armas - recayendo en su mayor parte en personas civiles. [ver Tabla \#1.] Para los miembros del ejército implicados en delitos políticos en esta etapa, en el 70\% de los casos fueron compurgadas sus penas con la prisión sufrida, pagaron multa, fueron suspendidos de empleo o gozaron de alguna amnistía real. ${ }^{32}$

Si se centra la atención en los delitos mayormente procesados [ver Tabla \#1], es visible que la actuación de la Comisión no estaba dirigida a la represión liberal -como puede deducirse de su contemporaneidad con las peninsulares- sino que su alcance era más abarcador: la Comisión no era simplemente en tierras cubanas un fenómeno circunstancial para la represión política luego del trienio, ni solo para hacer frente a las tendencias conspirativas orquestadas con apoyos continentales. La Comisión constituyó una vía expedita para garantizar el orden público al interior de la colonia, un marco para la actuación sumaria e inmediata, fuera del sistema procedimental ordinario, y con una proyección suficientemente ambigua de sus competencias como para dejar libertad discrecional al Capitán General sobre qué actos de desorden derivar hacia su control estrecho. El carácter militarizado del orden público colonial se fundamentaba pues en una fórmula extra-ordinem de tradición antiguo-regimental, reconocida por el resto de las

32 ANC. Fondo Comisión militar, leg. 131, exp. 2. 
justicias y por tanto legítima dentro del funcionamiento jurisdiccional prevaleciente -lo que no significa vista con complacencia.

La rigurosidad de las penas y las intenciones de disciplinamiento social $^{33}$ no fueron incompatibles con una graduación en la consideración de circunstancias particulares, ${ }^{34}$ ni con una unicidad de criterios en cuanto a la manera de proceder. Si bien es cierto que el tribunal se mantuvo a disposición de la Capitanía General para intervenir de manera sistemática sobre desórdenes públicos, sublevaciones, sospechas políticas, etc., en la actuación cotidiana de los fiscales y vocales se respetaron fórmulas procedimentales consecuentes con una voluntad de orden. Ello deja poco espacio a la más común opinión historiográfica sobre la arbitrariedad de la Comisión militar, generada como resultado de la publicidad que obtuvo la represión de la llamada conspiración de La Escalera en 1844 -sobre la que regresaremos luego.

Los fiscales de la Comisión tenían la capacidad de oficiar a las autoridades locales de los partidos judiciales (Alcaldes ordinarios, Jueces pedáneos, Comisarios de barrio) y de los distritos militares (Gobernadores, Tenientes gobernadores y otras autoridades militares como Capitanes de Armas o de Milicias) para la puesta en marcha y ejecución de los trámites o diligencias de toma de declaración y ratificación de testigos, citación, interrogatorio, persecución de prófugos, etc.; los cuales debían responder con inmediatez y presteza a dichas solicitudes. ${ }^{35}$ Por ejemplo, por Circular del Gobierno Superior Político de 21 de febrero de 1826 los Capitanes de Partido "debian remitir con prontitud

${ }^{33}$ En las sentencias a muerte, por ejemplo, se ordenó la exposición de la cabeza de los sentenciados en las inmediaciones del lugar del crimen, y para suprimir sublevaciones esclavas se fusilaban a los líderes en presencia de miembros de todas las dotaciones del territorio próximo. ANC. Fondo Comisión Militar, leg. 131, exp. 2.

${ }^{34}$ Incluso si los delitos eran menores - hurtos de poca monta y acusaciones similares- se computaba la pena con la prisión sufrida mientras se sustanciaba la causa, en promedio entre 8 meses y 1 año.

${ }^{35}$ Según documentos consultados de los años 1850-1852, entre las fechas de envío de los oficios por parte de los fiscales solicitando diligencias y la remisión de las mismas no transcurrían más de 40 días, siendo el promedio 11,7. Libro de salida de correspondencia de la Comisión Militar (18491852). ANC. Fondo Miscelánea de libros, 4675. 
todas las diligencias y requisitos que se les solicitasen"; o en el caso de que la causa se iniciase en juzgado ordinario según disposiciones de la Capitanía General el procedimiento se sustanciaba por la autoridad que la iniciaba hasta que estuviese lista la instrucción sumaria, y entonces se remitía al tribunal militar en La Habana. La concepción del proceso como sustanciación rápida, breve e inmediata, "en el término más corto posible", se expresó en la omisión de procederes dilatorios y la agilidad de las consultas y remisiones.

El hecho de que las justicias primarias y las autoridades militares tributasen al tribunal en cuanto a trámites locales y en la persecución de reos tiene que ver con el limitado poder de acceso efectivo al territorio que tenían los fiscales de la Comisión, radicada en la capital. Su radio de competencias real durante los primeros años fue escasamente el área occidental, o, en fórmula más reducida, La Habana y Matanzas. ${ }^{36}$ A medida que el número de procesos llevados a la Comisión aumentó con el transcurso del tiempo, ${ }^{37}$ y sobre todo, cuando cada vez fueron más frecuentes las causas remitidas desde los departamentos central y oriental, la capacidad de sus cuatro fiscales para efectuar de manera ágil la sustanciación se vio disminuida, por lo que el tiempo de prosecución se incrementó a más de un año y las quejas de estos se reflejaron en los informes a la Presidencia desde principios de $1830 .^{38}$

${ }^{36}$ Para el período 1825-1836 el departamento occidental de Cuba, según plano de 1831, comprendía las jurisdicciones de La Habana, Guanabacoa, Santiago de las Vegas, Bejucal, Güines y Jaruco, además del Gobierno de Matanzas y las Tenencias de Gobierno de Nueva Filipina (Pinar del Río) y Fernandina de Jagua (Cienfuegos). De un total de 162 procesos enumerados en la propia estadística de la Comisión durante dicho arco temporal, el 54.9\% (89 casos) corresponde a las áreas de las 6 jurisdicciones que conforman el radio de la capital; mientras el 25,9\% (42 procesos) comprenden la jurisdicción matancera, el 9,3\% (15 expedientes) a Nueva Filipina y un 9,9\% (16 expedientes) a jurisdicciones del resto de la isla; estos últimos relacionados casi exclusivamente con desórdenes políticos. ANC. Fondo Comisión militar, leg. 131, exp. 2.

${ }^{37}$ En el segundo semestre de 1836 fueron radicadas 69 nuevas causas, que se unieron a los 67 pendientes del semestre anterior. Solo en junio fueron vistas en Consejo de Guerra 10, mientras en el segundo semestre 38 .

${ }^{38}$ Los fiscales colocaban notas sobre la tardanza en las diligencias distantes: "Desde el primero de julio último hasta el 23 de octubre no se ha hecho otra cosa que practicar varios careos entre Hernández y testigos, así como evacuar infinidad de citas que por morosidad e inconvenientes que ofrecen las largas distancias en que residen 
Es por esa razón que progresivamente aumentaron las capacidades de efectuar solicitudes a otros tribunales y se multiplicaron los fiscales comisionados en las ciudades más importantes de la colonia durante los años 1838-1842, ${ }^{39}$ lo que está en la base del descontento que generaba entre las primeras justicias. La gestión del orden fue siempre la causa esgrimida para concretar dicha presencia territorial y garantizar la intervención castrense.

En definitiva, el resultado de todas esas medidas fue palpable: gracias a la agilidad de la sustanciación (los procesos demoraban como promedio entre 9 y 18 meses $^{40}$ ) en relación con la actuación de la justicia ordinaria (que podía tardar años en dictar sentencia ${ }^{41}$ ) la Comisión militar constituyó el instrumento ejecutivo más eficaz para garantizar

los individuos a quienes comprenden aquellas, han absorbido mucha parte del tiempo..." ANC. Fondo Comisión militar, leg. 131, exp. 2.

${ }^{39}$ Por disposiciones del Auditor de Guerra en 1838 aprobadas por el Capitán General Miguel Tacón quedó establecido que en Santiago de Cuba, Puerto Príncipe y Trinidad los procesos remitidos por las justicias ordinarias sobre delitos de competencia del tribunal excepcional se radicarían en el juzgado del Comandante militar de las respectivas provincias, el cual luego de remitir la sumaria al tribunal habanero para su conocimiento, designaría fiscal y secretario que "sustancien el proceso con arreglo a ordenanza, y concluido y agregada la defensa del reo se remita al Sr. Presidente de la Comisión Militar para que se sentencie en el consejo de la misma." Luego esa disposición se hizo extensiva a otras ciudades, aunque las causas más graves continuaron viéndose en la capital. ANC. Fondo Comisión militar, leg. 1 exp. 1.

${ }^{40}$ ANC. Fondo Comisión militar, leg. 131, exp. 2, Estadísticas fiscales de las causas procesadas por la Comisión militar entre 1826 y 1840; y leg. 132 exp. 1, Estadísticas fiscales de las causas procesadas por la Comisión Militar entre 1840 y 1856. Unos pocos procesos fueron extraordinariamente lentos. En junio de 1836 existían 10 causas pendientes de años anteriores: una por asesinato radicada en diciembre de 1833 que para la fecha se ratificaba por segunda vez (2,5 años); otra por asalto y robo radicada en abril de 1831, pronta para verse en consejo de guerra entonces (5 años); y el resto radicadas entre abril-junio de 1834 o inicios de 1835 a bandidos y salteadores de caminos, que continuaba "en plenario" o "prontas para verse en consejo".

${ }^{41}$ El regidor del Ayuntamiento habanero José María Calvo en una memoria enviada a la Reina en 1835 sobre la administración judicial en la isla expresaba: "El castigo pronto de los delitos casi nunca llega a verse en la Isla de Cuba, a menos que habiendo alguna parte interesada y con medios, logre poner en movimiento a jueces y escribanos; pero en siendo causas de oficio se eternizan, jimen [sic] los presos a veces diez y doce años en las cárceles, siendo una gravosa carga para los fondos municipales (...)" CALVO, José María. Representación dirigida a S.M. la Reina Gobernadora sobre reformas en la Administración de justicia en la Isla de Cuba, en 25 de noviembre de 1834, Madrid: Imprenta de Don Lázaro Fernández de Angulo, 1835. p. 11. 
la "seguridad pública", lo que era posible también debido la ausencia de efectivos policiales profesionales.

A partir de los años 1840 y dado el incremento del número de fiscales, estos se rigieron por unas Instrucciones de 75 artículos ${ }^{42}$ donde se precisaba cómo actuar en caso de procesos fuera de La Habana. Su existencia se explica naturalmente por el desconocimiento jurídico de los oficiales nombrados. En realidad, de todos los participantes en los procesos el único con formación letrada era el Asesor, que únicamente intervenía para aconsejar a fiscales y vocales en caso de consulta, y para la revisión de los procesos antes de pasarlos al Capitán General para la aprobación definitiva de la sentencia. El resto eran miembros del ejército, jueces y ejecutores legos, con conocimiento en el mejor de los casos (así sucedía por ejemplo con los fiscales permanentes) de lo estipulado por las Ordenanzas militares para la prosecución de las sustanciaciones y los consejos de guerra. ${ }^{43}$

Si bien es cierto que la Comisión conocía de manera exclusiva de los delitos de carácter político - de ahí que la represión de todas las conspiraciones, levantamientos y procesos sediciosos suscitados en el segundo cuarto de siglo fuera atribuida a dicho tribunal ${ }^{44}$-, la mayor parte de su trabajo cotidiano en términos cuantitativos estuvo dirigido al control de la criminalidad, el bandolerismo y el mundo esclavo, ${ }^{45}$ lo

${ }^{42}$ INSTRUCGIÓN para fiscales, 1846. ANC. Fondo Comisión militar, leg. 83, exp. 8.

${ }^{43}$ Sobre la composición del ejército en Cuba durantela primera mitad del siglo XIX lamentablemente no existen estudios suficientes que permitan analizar la proveniencia y formación académica de sus miembros ni la trascendencia del hecho de nombrar oficiales de manera permanente para formar parte de la Comisión militar. El estudio más completo sobre el estamento militar cubano no abarca el período posterior a 1825: KUETHE, Allan J. Cuba 1753-1815, Crown, Military and Society. Knoxville: The University of Tennessee Press, 1986.

${ }^{44}$ Las más notorias: Conspiración del Águila Negra (1830), declaración constitucional del general Lorenzo en Santiago de Cuba (1836, procesos entre 1837-1842), Conspiración de la Escalera (1842, procesos entre 1843-1845), expediciones anexionistas del General Narciso López (18501851). ANC. Fichero del Fondo Comisión Militar.

${ }^{45}$ Por ejemplo, entre junio y diciembre de 1836 de un listado de 98 causas solo 7 son de carácter político ("escritos que compromete el orden público", "expresiones injuriosas a S.M.", "reuniones subversivas", "discurso sedicioso" con un folleto anónimo de igual consideración, "versos injuriosos 
que ofreció una apariencia de seguridad pública y control social que no podía garantizarse desde la jurisdicción ordinaria de justicia o a través las escasas fuerzas "policiales" insulares (los comisarios de barrio, los capitanes pedáneos y sus respectivos tenientes). En realidad, el complemento como fuerza territorial del tribunal militar lo constituyeron las Partidas perseguidoras de malhechores, dispositivos también de carácter excepcional y bajo la directa autoridad del Capitán General en calidad de "comisionados". Del rol fundamental que jugaba la Comisión militar "a cuyo celo se ha confiado principalmente la seguridad de esta Isla" se tuvo consciencia tempranamente, como lo expresó el propio Presidente del tribunal al máximo jefe militar en 1828 en ocasión de recomendar los méritos de sus fiscales y "la importancia de ella y de cuanto son dignos de atención los servicios poco comunes de los individuos que componen este Tribunal". ${ }^{46}$

\section{Autonomía y autoridad de un tribunal fundamental}

La "especialidad" del contexto cubano y el carácter expeditivo del tribunal militar fueron los argumentos utilizados para la ampliación de sus competencias y del margen de los Capitanes Generales para decidir los delitos de su conocimiento. ${ }^{47} \mathrm{El}$ camino que condujo a la autonomía del tribunal cubano partió de una fecha anterior a 1837,

y subversivos", además de otras dos por "conato de subversión"). Todo el resto comprende "asaltos y robos", "cuadrillas de bandidos", "salteadores de caminos", "portación de armas prohibidas", "asesinato" e "incendio". ANC. Fondo Comisión militar, leg. 131, exp. 2.

${ }^{46}$ Oficio del Presidente de la Comisión militar al Capitán General en enero de 1828. ANC. Fondo Comisión Militar, leg. 133, exp. 1.

${ }^{47}$ Esto último por Real Orden de 29 de septiembre de 1839, recogida en: CARAVANTES, José Vicente. Op. Cit. p. 302. En la misma Real Orden se decretaba la preferencia por los consejos de guerra ordinarios como juzgados especiales en territorios declarados en estados de guerra o de sitio, antes que las comisiones militares "sino estuviesen establecidas por disposición de los generales en jefe y estos conceptuasen necesaria su existencia", como era el caso de la colonia antillana. Esta declaración de preferencias se explica por la inconstitucionalidad de las comisiones militares señalada en el artículo 247 de la Constitución de 1837; pero en la práctica ni el carácter inconstitucional de estos tribunales ni la normativa para la regularización de la declaratoria del estado de excepción fueron atendidos en las Cortes hasta la segunda mitad del siglo. 
momento en el cual la legitimidad de las comisiones militares comenzó a ponerse en entredicho en las normativas liberales. Comportó, no obstante el resultado, interrupciones o fluctuaciones que dependieron de las coyunturas y tensiones sociales a que se enfrentaron los diversos Capitanes Generales en la Isla entre los años 1825 y 1856. Pero siempre se mantuvo en lo esencial el poder extendido del tribunal en relación con el panorama institucional de la colonia.

Según la orden de creación de las comisiones militares, la disposición de ejecución de sentencias correspondía al Capitán General una vez consultado por el Auditor de guerra. En caso de dudas del Auditor, el Capitán General como presidente de la Audiencia territorial dispondría de tres Oidores para emitir dictamen, el cual sería elevado al Consejo Supremo de Guerra en caso de subsistir conflicto, o decidiría el propio Capitán General. Este mecanismo de legitimación de la actuación de la Comisión militar a partir de su reconocimiento por parte del dispositivo judicial tradicional no se operó en la práctica, dado que las sentencias fueron sancionadas por resolución del Capitán General sin consultar con magistrados de la Audiencia, únicamente con el Asesor primero de gobierno o con el Auditor de guerra, ${ }^{48}$ que generalmente actuaban a su vez como Asesor de la Comisión. De esta facultad concedida a los Capitanes Generales para ejecutar las sentencias sin previa consulta magistral se derivó la denominación de las comisiones como ejecutivas, aunque cotidianamente se asumió la denominación en su sentido de actuación judicial abreviada. ${ }^{49}$

${ }^{48}$ En una consulta del Auditor de Guerra en 1845 se especifica en lo relativo a la anulación de sentencias: “(...) Discutir de la aprobación de sentencias por este solo particular [el cobro de costas], cuando en los demás estaba conforme a justicia, hubiera sido preciso convocar el Consejo de revisión de los Magistrados de la Audiencia, único que puede anular una sentencia o parte de ella, cuando el Auditor no la considera arreglada y como este trámite habría ofrecido larga dilación en causa tan complicada y voluminosa [se refiere a la conspiración de La Escalera] entorpeciéndose la pronta administración de justicia, que tan necesaria se hacía en aquellos críticos momentos, contemplé más prudente y acertado desvirtuar los efectos de dicha cláusula...". ANC. Fondo Comisión Militar, leg. 133, exp. 1.

${ }^{49}$ Así expresaba el Asesor interino de la Comisión en octubre de 1851: " $Y$ como por las superiores disposiciones vigente de la Capitanía General a que se contrae mi consulta ha dirigido este Tribunal sus promociones a las Autoridades competentes locales, como medio más rápido para la práctica de las diligencias 
De similar manera sucedía en los casos de conflictos jurisdiccionales. ${ }^{50}$ La designación de la Audiencia como la autoridad con competencias jurídicas sobre la Comisión y el reconocimiento de su presencia histórica como instancia de poder tendió a soslayarse a medida que el equilibrio de fuerzas políticas en la Isla se inclinó hacia la Capitanía General a partir de los años $1830 .{ }^{51}$ Ello se evidenció en la paulatina independencia procesal del tribunal excepcional, en el cual prácticamente todas las sentencias y los casos de competencias y sobreseimientos se verificaron con el jefe militar de la Isla. ${ }^{52}$

La justificación dada para ello no era otra que la desconfianza del mando político-militar hacia las instituciones judiciales tradicionales, un giro notable en los mecanismos históricos de limitación del poder operado a partir de $1837^{53}$ :

respectivas que corren en las causas de que conoce con arreglo a su índole ejecutiva, cumplimentándose así las providencias desde su erección hasta hoy sin trabas ni oposicón alguna (...)". Íbidem. El resaltado me pertenece.

${ }^{50}$ En los cuales, según la misma Real Orden de 1824, el Capitán General debía pasar la causa a un Oidor y al Auditor de guerra para que decidieran la correspondencia; y luego de esto, si persistía duda, a otros tres Oidores de la Audiencia.

${ }^{51}$ Aunque no hay espacio en estas páginas para explicar el fortalecimiento de la autoridad del Capitán General en términos jurídico-institucionales durante los años que transcurren entre 1825 y 1856 (en los cuales deviene el centro neurálgico de todas las relaciones de poder en la Isla) no puedo dejar de remitir a dos trabajos imprescindibles actualmente sobre el tema: ALONSO ROMERO, María Paz. Cuba en la España liberal (1837-1898). Madrid: Centro de Estudios Políticos y Constitucionales, 2002, particularmente capítulo 1 pp. 17-35; y FRADERA, Josep M. Colonias para después de un imperio. Barcelona: Edicions Balleterra, S.L., 2005, en particular su capítulo 2 La construcción del mando supremo, pp. 183-327.

${ }^{52}$ Los sobreseimientos por ejemplo nunca pasaron por otra autoridad que el Capitán General, según establecía una real orden de 18 de abril de 1825, que declaraba que "conforme al espíritu de la real orden de 18 de enero, a la causa pública y a la mejor administración de justicia" se consultasen con los Capitanes Generales las providencias de sobreseimientos en las actuaciones de las comisiones militares ejecutivas. Y lo mismo sucedía con los sobreseimientos de otros juzgados hacia la Comisión Militar: en julio de 1851 el Auditor de Guerra le indicaba al Capitán General que “(...) se diga al Gobernador de Matanzas que en lo sucesivo no remita a esta capital los reos, antes de declararse si corresponde o no al Tribunal de la Comisión, conocer del asunto, cuya calificación compete exclusivamente a V.E., y no al juzgado que acuerde el sobreseimiento.” Ambas citas de: ANC. Fondo Comisión Militar, leg. 133, exp. 1.

53 Sigo en esta reflexión a FRADERA, Josep M. Colonias para después de un imperio. Barcelona: Ediciones Balleterra, S.L., 2005. p. 220 y ss. No puedo dejar de señalar aquí, aunque sea sumari- 
"...el sigilo, que debe ser tan sagrado en toda causa criminal en estado sumario, y doblemente en las de estado, se comprometería a la suerte de los encuentros y a la confianza de los varios ministros que habian de intervenir en decidirlos, y aunque por su carácter y probidad ofrecen la mayor seguridad, no siempre podría contarse con esas garantías, ni con la imparcialidad de los votos." ${ }^{54}$

Y, aún más que eso, una desconfianza expresamente radicada en los magistrados locales:

"...tiene un inconveniente el que ejerza la magistratura un natural (...), emparentado y extremadamente relacionado, asi debiera en esta capital tenerse presente dicha circunstancia. El parentesco y las relaciones sacadas de haber vivido siempre en el país, hacen al hombre flexible, o le colocan por lo menos en el conficto que resulta de los estímulos de la sangre y de la amistad por una parte, y de los deberes anexos a un cargo público por la otra." ${ }^{55}$

Identificar las causas procesadas en la Comisión como "de estado" significaba homologar su actuación con la defensa de una política militarizada de gobernación colonial, lo que concedió amplio margen de libertad al tribunal excepcional. En ello radicó su poder y su significativa diferenciación con las comisiones militares establecidas en la Península: en Cuba la Comisión militar no fue una respuesta coyuntural a una contingencia política, como ha quedado dicho; allí transmutó en dispositivo de un nuevo modelo de gobierno colonial en virtud del disciplinamiento social ${ }^{56}$, de ahí su permanencia ininterrumpida por

amente, la importancia capital que revistió la exclusión constitucional de Ultramar en 1837 por lo que significó en términos de legitimación de la excepcionalidad colonial, de continuidad de la pluralidad jurisdiccional heredada en las formas de gobierno, y porque explica en gran medida, aunque no exclusivamente, la expansión y normalización de la jurisdicción militar como forma de control social durante el segundo cuarto del siglo. Un análisis sobre las consecuencias de la quiebra constitucional de 1837 puede encontrarse en: FRADERA, Josep M. La Nación Imperial (1750-1918), Op. cit., particularmente V. II, capítulo 9.

${ }^{54}$ Consulta del Auditor de Guerra al Capitán General, agosto 4 de 1838. ANC. Fondo Comisión Militar, leg. 22, exp. 6. El resaltado me pertenece.

${ }^{55}$ Carta del Capitán General Joaquín Ezpeleta al Ministerio de la Guerra sobre atribuciones de la Comisión militar, 31 de agosto de 1838. Ibidem.

${ }^{56}$ El debate historiográfico sobre el contenido de la expresión "disciplinamiento social" es amplio. Para una síntesis del mismo ver MANTECÓN, Tomás. Formas del disciplinamiento social, 
décadas. Y ello porque, en sus orígenes las Comisiones de 1824, tanto en España como en Cuba, habían sido tribunales para combatir una oposición política respecto a un orden que se podía identificar con el de Antiguo Régimen; pero evidentemente el cambio liberal varió la naturaleza de esa "disidencia política". Por otro lado, nuevos problemas sociales vinculados a la esclavitud de masas hicieron aparición durante las primeras décadas del siglo en Cuba. Así, las funciones de la Comisión se reformaron, por ampliaciones sucesivas, hasta convertirse en un tribunal de promoción de una disciplina social y política que garantizase el funcionamiento del sistema de dominio colonial, el cual dependía de la productividad de una economía esclavista y del pacto de seguridad y garantías productivas entre las élites locales y el gobierno militar. Lo confirma la respuesta enviada a la Audiencia territorial de Puerto Príncipe cuando en 1825 protestó al gobierno de Madrid la conservación del tribunal excepcional en la mayor de las Antillas mientras eran suprimidos los correspondientes peninsulares:

"...que el Capitán General podía quitar o poner las Comisiones según creyese conveniente, en uso de las amplias facultades que le estaban conferidas y siendo acaso muy diferentes los fundamentos que inclinaron el Real ánimo de S. M. á extinguir las Comisiones Militares en la Península de los que puedan mediar para suprimir la de la Habana, en consideración a la situación crítica de aquella Isla y a los conocidos esfuerzos de los sublevados de América para apoderarse de ella, e introducir emisarios y escritos incendiarios dirigidos a promover la revolución, y que en el día debe conceptuarse esa Isla como un punto meramente militar." 57

Bajo el espectro de la regularización de un estado de sitio se daba cobertura a la aplicación permanente y postergada del tribunal extraordinario bajo la órbita de la Capitanía General, lo que devino en una normalización del manejo extraordinario del orden público, en relación con la actualización o modernización de la constitución militar del

perspectivas históricas. Revista de Historia Social y de las Mentalidades, vol. 2 (14). p. 265-298. Aunque debe ser examinado este tema para un contexto de sociedad corporativa (como la cubana del siglo XIX), en este texto entiendo "disciplinamiento social" en su sentido de: producción de un vocabulario sobre el orden social y consecución de una práctica punitiva asociada al mismo.

${ }^{57}$ ANC. Fondo Gobierno Superior Civil, leg. 1469, exp. 58001. 
territorio insular que se operaba en esos años, cuando el enemigo dejo de ser solo exterior para buscarse, también, interiormente. Sin embargo, la ordinarización de lo extraordinario no sorprende en la tradición jurídica de Antiguo Régimen, cuyo pluralismo jurídico estaba basado esencialmente en la incorporación y metabolización de lo nuevo, en todos los casos surgido en circunstancias "distintas" y como respuesta extraordinaria. Pero que ello fuera tradicionalmente concebible no significaba que fuese aceptado de buen grado por parte del entramado de instituciones contemporáneas, lo cual explica la protesta de la $\mathrm{Au}-$ diencia cubana en 1825.

No resulta extraño sin embargo el apoyo que recibió la decisión de conservar activo el tribunal excepcional luego de 1825 por una parte de la oligarquía cubana, en momentos en que se buscaba un consenso político en torno al Capitán General. Fue apoyada la decisión por los condes de Mopox y de Jaruco, de Fernandina, de Buenavista, y de la Reunión, y por José Ricardo O’Farrill y el Marqués de San Felipe y Santiago, sacarócratas todos, con concesiones de grandeza de España algunos y vínculos con la alta jerarquía militar y el gobierno metropolitano. ${ }^{58}$ Además, el importante grupo de indianos traficantes de mano de obra esclava que conformaban la llamada "camarilla palaciega" en torno a la Capitanía General también se alió a la propuesta de conservación del tribunal, figurando entre los apoyos de la medida Joaquín Gómez, luego miembro fundamental del poderoso e integrista Comité Español. ${ }^{59}$ En este punto, los intereses de los diferentes grupos de presión cubanos confluían en el establecimiento de una política de mano dura que garantizase las ganancias de la hacienda cubana y por extensión de la peninsular, base de toda la pirámide político-económica que se forjarían en tensión en los años sucesivos.

${ }^{58}$ FERNÁNDEZ CAYUELA, José G. Relación colonial y élite hispano-cubana en la España del XIX. Salamanca: Ediciones Universidad de Salamanca, Stud. hist. H ${ }^{a}$. Cont., 15. p. 29.

${ }^{59}$ FRADERA, Josep M. Op. Cit., p. 172; BARCIA ZEQUEIRA, María del Carmen. Élites y grupos de presión. Cuba, 1868-1898. La Habana: Ediciones Ciencias Sociales, 1998. p. 3. 
Ya con Vives la Comisión militar conoció de una extensión de sus competencias hacia terrenos más cotidianamente operativos relacionados con el control de los crímenes de sangre, al disponer el jefe superior de la Isla que todas las causas por portación de armas prohibidas y los delitos de robo y asesinatos en el extrarradio habanero fuesen sustanciadas en sus consejos de guerras en el término más inmediato ${ }^{60}$ Pero fue durante el mandato de Miguel Tacón (1834-1838) que el tribunal se convirtió en recurso imprescindible de la Capitanía General frente a la formas jurisdiccionales y de gobernabilidad locales, y en un útil instrumento de represión del liberalismo insular, como se evidenció tras la declaración constitucional del General Manuel Lorenzo en Santiago de Cuba en 1836, acción que precipitó los acontecimientos hacia la exclusión constitucional de los territorios monárquicos ultramarinos un año después.

Superando lo sucedido casi una década antes, cuando el 29 de julio de 1834 fue nuevamente ordenada la disolución de las Comisiones militares (reinstaladas en la Península durante la primavera de ese año), la oposición del Capitán General a la orden se transformó en un reforzamiento de la autoridad del tribunal. En primer lugar, y de manera similar a lo sucedido 9 años atrás, la inmediata comunicación de la Real Orden supresora por parte de la Audiencia de Puerto Príncipe a las justicias menores fue objetada por el jefe militar, quien inmediatamente dictó una circular para conservar el tribunal “(...) en el libre ejercicio de las atribuciones que se le han conferido en la Real Cédula de su erección y que ha estado desempeñando hasta ahora en bien de la seguridad personal y tranquilidad pública con saludable temor de los malvados, y con sincera aprobación de todos los buenos ${ }^{\$ 1}$, amparado, según sus propias palabras, en lo sancionado por el Estatuto Real vigente en Cuba desde el 1 de junio de

${ }^{60}$ Este dato está reflejado en una Circular de 25 de mayo de 1832 del Capitán General Mariano Ricafort, recogida en: APÉNDICE de la Relación del gobierno superior y Capitanía General de Miguel Tacón. La Habana: Imprenta del gobierno y capitanía general, 1838. Ricafort también intentó ampliar las facultades de la Comisión militar en septiembre del propio año, pero al no poder fundamentarlo con una coyuntura de peligrosidad social inmediata no se llevaron a efecto sus propuestas. ${ }^{61}$ ANC. Fondo Gobierno Superior Civil, leg. 1469, exp. 58001. 
ese año. ${ }^{62}$ Refiriéndose a la situación que se suscitó entonces, Joaquín Ezpeleta, quien sucedería a Tacón en el alto mando de la Isla, expuso, en términos que no necesitan comentarios:

"Si mi digno antecesor logró en las críticas circunstancias en que se encuentra la madre patria con respecto a los dominios de Ultramar, mantener la tranquilidad en esta Isla bajo el gobierno de la metrópoli, consistió en gran parte, en que S.M conservó ilesas las atribuciones de la Comisión Militar de la gravedad y trascendencia del mal, impuso a aquellos ministros [de la Audiencia]; sostuvo la Comisión militar, y manifestó al Gobierno Supremo en Comunicación de 28 de febrero de 1835 (...) que era imposible responder de otra manera de la seguridad de la Isla. S.M. oyó sus razones (...) y la Comisión se sostuvo, porque no podía dejar de suceder así. Sin ella con toda la plenitud e independencia inalterable de sus facultades no habría sido posible conservar la Isla de Cuba." ${ }^{\$ 3}$

La consulta que en su momento remitió a Tacón el Auditor de Guerra es sugerente en cuanto a la manera en que se manejaron las reticencias locales, con una argumentación basada en la necesidad de enfrentar "lo inmediato" del peligro socio-político antes que prestar atención a la legitimidad legal (por constitucional) o no de la Comisión Militar. Para el Auditor, en Cuba se daban tres situaciones urgentes e impostergables:

\begin{abstract}
"Primero; la seguridad de las haciendas de campo, y de los caminos públicos. Las primeras aunque servidas por gran número de negros, exige la prudencia de tenerlos desarmados. $Y$ solo lo están dos o tres personas blancas que cuidan de su gobierno: los dueños pasan una temporada en las mismas, si son cuantiosas, y en las cortas viven de asiento; y unos y otros expuestos a los atropellados por una docena de forajidos armados: quedando del mismo modo los caminos para la extensión de sus fincas por la soledady desamparo en que se ven, a causa de la falta que hay aun de población.
\end{abstract}

${ }^{62}$ En el programa que los liberales llevaran a las Cortes de 1834 se exigía, coherente con las máximas del liberalismo, que "ningún español será juzgado por comisiones, sino por tribunales establecidos por la ley antes de la perpetración del delito"; lo que, junto con el resto de sus exigencias, fuera rechazado por los absolutistas, quienes sancionaron, en alianza con los liberales moderados, el Estatuto. La situación que se sucedió entonces llevó a la primera guerra carlista y a las Cortes liberales de 1837, pero en la distante colonia nada cambió. VILLACAÑAS BERLANGA, José Luis. Historia del poder político en España. Barcelona: R.B.A. Libros, S.A., 2014. p. 431-432.

${ }^{63}$ ANC. Fondo Gobierno Superior Civil, leg. 1469, exp. 58001. 
Segundo; las sublevaciones de las esclavitudes, que no han dejado de repetirse; que comienzan por una finca matando a todo viviente blanco, y saliendo luego a las contiguas abrazarian a toda la isla sino fueran en el momento reprimidas.

Tercero; las conspiraciones interiores que siempre se fraguan en las poblaciones de consideración donde existen los espíritus revoltosos, los ambiciosos y viciosos que van a medrar con el trastorno, con la ruina de los que tienen y a cuya riqueza aspiran; a los que se agregan los amigos de novedades; otros que por su diferente clase están propensos, y la muchedumbre que sin designio determinado aumenta las masas. ${ }^{\prime 64}$

Se trajeron a colación los tres miedos con que se manejaba la política represiva en la Isla. En primer lugar y según el argumento manejado por el poder político, la preocupación más apremiante resultaba ser el bandolerismo por lo que representaba de peligro a la propiedad privada y la seguridad individual, un espectro figurativo en el que cabía mucho y que sirvió muy bien a los efectos de la ficción creada por el alto mando sobre la peligrosidad social en Cuba. ${ }^{65}$ Fue la figura más abarcadora a través de la cual procesó la Comisión militar cubana, siendo consecuente con la Real Orden de su creación y con la actuación de las diversas Comisiones peninsulares. ${ }^{66}$ En segundo término el Auditor advertía sobre las sublevaciones esclavas, con un retórico manejo del miedo al negro y las consecuencias económicas y estamentales

${ }^{64}$ Ibidem. El resaltado me pertenece.

${ }^{65}$ Sobre el procesamiento por bandolerismo en la Comisión Militar cubana, remito al texto de mi autoría: De "bandidos" e "infidentes". Vocabularios del orden y tribunales militares en Cuba (1825-1868), de próxima publicación en Mélanges de la Casa de Vélazquez, Madrid.

${ }^{66}$ Es interesante asimismo la creación de Comisiones militares para enfrentar los ataques a la propiedad privada en otros contextos americanos durante los años posteriores a las independencias, lo que da una idea del carácter tradicionalista de la medida y su vinculación jurídica con el juicio a civiles por parte de autoridades militares, y más particularmente, con la represión del bandolerismo. Esto se evidencia en territorio argentino particularmente: MOLINA, Eugenia. Tras la construcción del orden provincial: las comisiones militares de justicia en Mendoza, 1831 y 1852. In: BARRIERA, Darío G. (org.), La Justicia y las formas de la autoridad. El Río de la Plata (Siglos XVII a XIX). Rosario: Red Columnaria/ISHIR/CONICET, 2010, pp. 83-105. Comisiones Militares fueron creadas también en el Brasil imperial y republicano, aunque con un matiz más político: BARRETO DE SOUZA, Adriana; MOREIRA DOMINGUES DA SILVA Angela. A organização da justiça militar no Brasil: Império e República. Revista Estudos Históricos, vol. 29, $\mathrm{n}^{\circ}$ 58, 14 julio 2016, pp. 361-380, particularmente pp. 366-367 y 370-371. 
de un movimiento de esta naturaleza. Finalmente, la amenaza política considerada siempre como "conspiración", el marco global o delito macro en el que se colocaba toda alteración del orden político, sobre todo desde la aparición en la escena pública del sujeto colectivo a partir de esos años, ${ }^{67}$ lo mismo en cuanto a "negradas" o "esclavitudes" que como "muchedumbres" o "masas".

Es en definitiva la misma retórica que amparó contemporáneamente a los diputados constituyentes para la exclusión de Ultramar (con un fuerte empuje de Tacón y su camarilla), y la que sustentaría la política colonial de las décadas sucesivas, basada en la exigencia de garantías para el sistema esclavista como fundamento del vínculo colonial y en la censura del liberalismo insular. Pero además, y de manera sintomática, constituyen las tres líneas principales de actuación del tribunal excepcional cubano hasta su supresión definitiva durante la década de 1850; un programa institucional perfilado hacia la conservación del equipamiento político-militar colonial, el régimen de propiedad y la seguridad pública como condiciones de posibilidad del sistema económico antillano.

Sin embargo, no fue un camino llano y libre de recusaciones judiciales la imposición de la Comisión militar como tribunal autónomo, a pesar de la voluntad de Tacón y sus sucesores. El hecho mismo de enmarcarse en una cultura jurisdiccionalista daba cabida a la aparición de tensiones con otros tribunales. La Audiencia en particular fue un fuerte escollo a superar por la Capitanía General en su pretensión de

67 Sobre este fenómeno en el contexto peninsular RISQUES CORBELLA, Manel. La militarización del control político sobre el territorio. Barcelona, Gobierno civil y orden público en la primera mitad del siglo XIX. (2014, Inédito). 
convertir la Comisión militar en su punta de lanza frente a las competencias de las autoridades tradicionales en materia de orden.

\section{Un nuevo concepto de orden}

En el momento en que Tacón asume el alto mando colonial los conflictos del tribunal excepcional con la Audiencia y en general con los tribunales ordinarios alcanzaban la esfera pública, como se patentizó en una misiva enviada por los vecinos de Bejucal al alcalde ordinario de esa ciudad en octubre de 1834. En la carta se ponía en entredicho la rectitud de los miembros de la Comisión militar por sospechas de corrupción y venalidad, y se ensalzaba por el contrario la honrada actuación de los tribunales reales. ${ }^{68} \mathrm{El}$ pulso entre la justicia militarizada y la civil se tornaba un asunto de imagen pública de los respectivos tribunales. La situación de conflicto se prolongó en los años inmediatamente sucesivos, sobre todo motivada por imputaciones a la Comisión a causa de procederes venales, y no quedaría decantada en favor del tribunal especial hasta la administración de Jerónimo Valdés, cuando un recambio de personal se efectúa. ${ }^{69}$

68 “...la experiencia les ha manifestado ya por dos veces, que la Comisión militar los ha juzgado [al bandido Valladares y otros] y se les ha visto brevemente puestos en libertad, vociferando ellos mismos, que al dinero y resortes de Valladares no habia resistencia en aquel tribunal especial. Los que firman están muy lejos de presumir que esa junta militar compuesta de hombres de honor, falte a su deber por consideraciones, y mucho menos que se les pueda atribuir la vil despreciable venalidad; aunque no deja de hacerles fuerza advertir, que cuando todos los hombres naturalmente desean que sus causas se ventilen en los tribunales ordinarios con arreglo a las leyes, y no por los estrictos y severos trámites de una Comisión, Valladares haya patentizado tan decididamente su empeño en que sea la referida Comisión la que conozca en el juicio..." Y añaden: “...se han unido [los vecinos] para que por el conducto de V. [el alcalde ordinario] llegue a manos de S.A. [la Audiencia Pretorial] esta sumisa representación, a fin de que los rectos magistrados que al príncipe representan (...), pongan en práctica sus luces superiores aquellas medidas que estimen más conducentes al alivio de la población, que no le queda otro arbitrio que ponerse hoy bajo su poderoso amparo (...)”. PINCELADA primera para el gobierno sombrío de las iniquidades cometidas por el asesor titular de la Comisión militar ejecutiva permanente establecida en la ciudad de La Habana, don José Ildefonso Suárez, por don Cristóbal Zurita y don Antonio Sánchez, fiscales que han sido de ella, y por otros notables personajes... La Habana: Imprenta de Luque, 1841.

${ }^{69}$ Me inclino a pensar que este escándalo de corrupción que implicó al asesor personal de Tacón está relacionado con la fuerte oposición al Capitán General por parte de los grupos criollos, pero 
El resultado catastrófico de la publicidad que alcanzó la venalidad de miembros permanentes del tribunal (dos fiscales y el asesor) en 1839, se confirmó con un severo dictamen por parte del Tribunal Superior de Guerra y Marina. ${ }^{70}$ Lo que llevó a Ezpeleta, Capitán General en la fecha en que recayó la Real Orden de condenación de lo actuado, a intentar restablecer la deteriorada imagen del tribunal, imprescindible entonces, según sus propias palabras antes citadas, para el gobierno y conservación de la Isla.

Un año antes, otro extenso caso de competencias entre un alcalde ordinario y la Comisión había obligado a Ezpeleta a repetir que el tribunal militar dependía exclusivamente del Capitán General, sin que pudiera entenderse sujeto a la Junta Superior de Competencias "que bajo ningún aspecto podía mezclarse en asunto alguno de dicho Tribunal, siendo en todo caso decisiva la determinación de la primera autoridad, con exclusión de cualquiera cuestión o reclamación de fuero o competencia" "1 ; lo que fue ratificado por Real Orden de 3 de noviembre de ese año. La Junta Superior de Competencias había sido establecida por Real Orden en diciembre de 1837, y fue vista por los tribunales comunes como el marco institucional para cuestionar las potestades procesuales de la Comisión. El clima de desafección hacia la Comisión en los tribunales ordinarios y entre la población en general resultaba innegable, y tenía que ver sin dudas con los ecos de la violencia represiva tras las declaraciones constitucionales de 1836 en Santiago de Cuba. ${ }^{72}$ Pero Ezpeleta no quería que

no cuento aún con fuentes suficientes para verificar esta hipótesis, que por otro lado corroboraría un vínculo estrecho entre el tribunal especial y el poder del mando supremo.

${ }^{70}$ Los venales procedimientos de la causa abierta en la Comisión contra la cuadrilla del bandido Valladares entre 1834 y 1838 llegó a la Corte por la insistencia del alcalde ordinario de Bejucal a quien los fiscales de la Comisión habían sustraído el proceso. La repercusión en Madrid fue tal que la Real Orden de 25 de diciembre de 1839, réplica del dictamen del Ministerio, declaró «nulo, por ilegal, improcedente, injusto y arbitrario el sobreseimiento de la citada causa» sentenciada por la Comisión, ordenando reponerla al estado que tenía antes de llegar a este juzgado y remitirla a la Audiencia territorial. PINCELADA primera para el gobierno sombrío... Op. Cit.. p. 23.

${ }^{71}$ ANC. Fondo Comisión militar, leg. 22, exp. 6.

${ }^{72}$ Entre 1836 y 1837 la Comisión procesó 19 causas directamente vinculadas con la proclamación constitucional del General Manuel Lorenzo en Santiago de Cuba, tanto contra personas civiles 
la situación se le saliese de las manos, ni en cuanto a la imagen severa que debía proyectar el tribunal, ${ }^{73}$ ni en cuanto a la pérdida de su valor fundamental a los efectos represivos, es decir, su capacidad de intervención inmediata sin las ataduras de la competencia jurisdiccional. Es por ello que puso todo su empeño en lograr la reivindicación de la Comisión como el "único medio" con que contaba el mando político en Cuba para garantizar el orden público y la conservación de la colonia. En misiva a Madrid expresaba:

“(...) los principios del Gobierno Supremo están identificados con la conservación a todo trance de este país unido a la metrópoli, y esto no puede conseguirse sin mantener robustecida la autoridad del Capitán General particularmente en tan delicadas circunstancias, y sin hacer imposible la hipótesis de que la Comisión militar sea perturbada en el ejercicio de sus funciones. Un solo ejemplar bastaria para que no hubiese causa grave en lo sucesivo que no fuese paralizada, siempre que asi conviniese a los criminales y a sus muchos favorecedores. Repito que en ese caso, menos malo sería extinguir la Comisión; y anticipo desde ahora mi opinión de que sin ella, ni yo ni ningún Capitán General podrá responder de la conservación de la Isla." ${ }^{74}$

Se aprecia aquí la superposición entre el ámbito de la constitución militar de los territorios en su versión modernizada (que otorgaba mayor importancia al orden económico y a la disciplina socio-política de los pobladores) y el del orden público, producto directo de la ley de abril de $1821 .^{75} \mathrm{Y}$ en efecto: a pesar de las réplicas de la Audiencia, de

como contra los militares que lo secundaron. Pero hubo también procesos judiciales en La Habana y otros puntos de la isla por la repercusión represiva del hecho. Ello significó un aumento inmediato del promedio de procesamientos por asuntos políticos en la Comisión: si entre 1825 y 1836 se procesaban por delitos políticos un aproximado de 4,8 causas anuales (78 expedientes computados para este período), entre 1836-1837 el índice ascendió a más del doble: 12,5. Solo se había producido un fenómeno similar de rápido aumento de procesos por causas políticas cuando la represión en 1830 de la llamada Conspiración del Águila Negra, que produjo 12 expedientes en el tribunal (34 reos). ANC. Fondo Comisión militar, leg. 131, exp. 2.

${ }^{73}$ El Auditor de Guerra le consultaba a Ezpeleta en agosto de 1838: "Valiera más que se aboliese la Comisión que despojarla de su prestigio y potestad.” ANG. Fondo Comisión militar, leg. 22, exp. 6.

${ }^{74}$ Ibidem.

75 "Orden público" ya claramente identificado como tal: “(...) A VE. [Capitán General] está confiado el de esta Isla [en referencia al "reposo social"], distinguida con el timbre de siempre fiel, y V.E. se halla autorizado, sin límites, para cuanto concierna a la conservación de tan estimable beneficio; empero sin necesidad 
las quejas de los vecinos y del desprestigio que siguió al conocimiento público del manipulado proceso contra Valladares en 1838, a finales de la década era la Comisión militar la entidad de orden público por antonomasia en Cuba. Su obligación de intervención inmediata en la represión de los delitos políticos no es el único indicio de esa función.

La estructuración en vertical que fue asumiendo el tribunal en los años inmediatamente posteriores a su creación ratifica su papel como institución de orden público. La progresiva disminución de la intervención de agentes externos al ejército y a la Capitanía General (asesores letrados, oidores de Audiencia), la naturaleza íntegramente militar de los procesos, su actuación de acuerdo a un código de procedimiento (las Ordenanzas militares), la asimilación de los bandos y órdenes del ejecutivo como pautas de actuación, y la subordinación exclusiva del tribunal al Capitán General la acercan a lo que se pretendía fuera una institución policial de nuevo tipo, esto es, que permitiese la intervención expedita del poder gubernativo en la represión del desorden social.

Aún un último elemento debe ser señalado en ese sentido, y tiene que ver con la naturaleza administrativa de su desempeño (en su sentido moderno). Los cuatro fiscales y los varios secretarios de la Comisión trabajaban en un espacio de oficina, vinculado a la Secretaría de Guerra de la Capitanía General, y contaban además con un Archivo propio. $^{76} \mathrm{El}$ tribunal se convocaba únicamente para la celebración de

de ocurrir a extraordinarias facultades, las soberanas determinaciones comunes y vigentes han marcado siempre el sendero que debe seguirse en la rápida sustanciación y decisión de las causas que se formen contra los que de cualquier modo procuren excitar la sedición y comprometer el orden público." Consulta del Auditor de Guerra sobre las competencias de la Comisión militar al Capitán General Joaquín Ezpeleta, 4 de agosto de 1838. Ibidem.

${ }^{76}$ En el informe del Presidente de la Comisión Brigadier Carlos de Vargas "para la entrega de todo al Sr. D. Francisco de Oclasco que le sustituye en la Presidencia del mismo" en 31 de diciembre de 1851, se expresa que existen en el archivo 157 legajos "donde se encuentran todas las causas que concluidas han cursado por el Tribunal desde su erección hasta la fecha", además de los 71 cuadernos correspondientes a la conspiración de La Escalera, que aparecen reunidos separadamente como "Sección de Matanzas". Especifica también Vargas que aparecen en la Secretaría los índices de la correspondencia mantenida por el Tribunal con la "Capitanía general y demás tribunales subalternos", y los "Libros corrientes" compuestos de: "Uno alfabético en que están 
los consejos de guerra una vez sustanciadas las causas, y los vocales recibían la convocación por orden de la Secretaría militar a través de las órdenes de Plaza, en las cuales se enviaban también las notificaciones a los oficiales defensores. Semestralmente se producían informes estadísticos cuantiosos para ser remitidos a la Capitanía General, y se llevaba un control estricto de toda la documentación producida y remitida. En este sentido, la Comisión militar contó con un funcionamiento que anticipó las exigencias que luego se hicieron en materia administrativa al resto de las instancias judiciales insulares, a partir de la reforma de la administración de justicia ultramarina del año 1855. Pero, sobre todo, funcionó y fue reconocida como una institución específica, localizable física y espacialmente, con un carácter ejecutivo concreto, y ello contribuyó notablemente a su proyección represiva. ${ }^{77}$

Pero esa caracterización como institución moderna queda inmediatamente acotada por los elementos de carácter tradicional que la conformaban, es decir, su propia legitimidad en tanto expresión de un "ordo non servatus" y la lógica corporativista en la que se desenvolvía. ${ }^{78}$

anotados todos los individuos que han sido juzgados por este Tribunal; Otro en que se anotan las causas que se extraen del archivo, con expresión de las autoridades o fiscales a quienes se entregan, las fechas de ello y devolución; Otro en que se anotan las causas que se radican en el juzgado; Otro en que se anota en extracto la correspondencia que lleva este Tribunal con la Capitanía General y demás autoridades superiores; Otro en que se anota en extracto la correspondencia que lleva este Tribunal con las autoridades subalternas de esta Isla; y Otro en que se anota en extracto la que se lleva con el Sr. Asesor". Además aparece especificado el mobiliario con que contaba la Comisión: taburetes, escaparates (para el archivo y para uso de los fiscales) mesa, tapete para cubrir la mesa de los Consejos de Guerra, tinteros, etc. ANC. Fondo Comisión Militar, leg. 133, exp. 1.

${ }^{77}$ Sobre la burocratización de la administración de justicia y su materialización (oficinas, gastos de escritorio, estadísticas, etc.), sigo en esta reflexión el análisis de: PIAZZI Carolina A. Administración y materialidad: una etnografía del Juzgado del Crimen del Rosario (Argentina, segunda mitad del siglo XIX). Historia Crítica, nº 63, 2017, pp. 53-74.

${ }^{78}$ La insistencia en el carácter corporativo del tribunal excepcional se ratifica en su consideración como colectividad, y únicamente en esa virtud, como poseedora de jurisdicción, lo que es decir, de reconocimiento público y poder. Un ejemplo baste: “(... $)_{i}$ Con qué facultades, con que investidura y bajo qué aspecto pudieron un asesor, el presidente y el fiscal dictar un fallo semejante, usurpando las atribuciones colectivas del juzgado? Este lo compone la reunión solemne de todos los vocales, que es la que tiene jurisdicción, según lo convencen los textos de la ordenanza, las leyes generales del reino, y todos los principios del derecho..." PINCELADA primera para el gobierno sombrío... Op. Cit. p. 14. 
Todo lo cual resultó en definitiva en una extraña hibridez que imposibilitó posteriormente su conservación, como veremos más adelante.

Sin embargo, la Comisión militar ilustra en su funcionamiento un nuevo concepto de orden, dada la intención ejecutiva y poco jurisprudencial de su actuación. El tribunal militar fue a un tiempo preventivo -su condición de "permanente" así lo estableció- y represivo, como hemos analizado hasta ahora. Encarnó la instauración de una política colonial de control militarizado del orden social, como la única alternativa practicable de intervención gubernativa dentro del contexto jurídico-tradicional cubano, en el cual el manejo de los desórdenes pasó por la vía castrense. Al transcurrir los años su actuación se perfiló cada vez más hacia un entendimiento ejecutivo de su contenido, cada vez más desembarazada de los hilos de la competencia jurisdiccional y la revisión por magistrados; sin dejar de ser, esencialmente, una institución producto del Antiguo Régimen y por tanto inmersa en la compleja dinámica de continuidad/cambio que acontece en el siglo XIX iberoamericano.

\section{Los objetos de política y de seguridad pública}

A medida que se multiplican las autoridades directamente subordinadas a la Capitanía General (los Tenientes Gobernadores y los capitanes pedáneos están presentes a partir de los años 1845-1855 en casi toda la geografía insular), y otras vías ejecutivas se ponen en marcha (el expediente gubernativo y los llamados expedientes de policía), el rol protagónico de la Comisión en materia de orden público empieza a ser disminuido. Pero todavía durante la década de 1840 la Comisión militar se impondría en el cotidiano de la práctica de gobierno militar de la colonia -de hecho, con episodios de extrema violencia en algunos períodos.

Hasta esas fechas, la Comisión había actuado como contraparte o dispositivo del mando supremo en La Habana frente a la actuación relativamente autónoma de la Real Audiencia Territorial radicada en Puerto Príncipe, cuyo radio de incidencia mayor eran las provincias central y oriental de Cuba. Pero en 1840 comienza a actuar una Au- 
diencia pretorial en La Habana, ${ }^{79}$ con vínculos más estrechos con la Capitanía General, que mal se avenía con el antiguo instituto políticojudicial del centro de la Isla. La instalación de la Pretorial fue el fundamento de Jerónimo Valdés, Capitán General entre marzo de 1841 y septiembre de 1843, para disminuir las "extendidas" facultades de la Comisión militar por circular de 7 de abril de 1841, "variadas las circunstancias" que habían obligado a sus antecesores a atribuir facultades no numeradas originalmente en el texto de fundación del tribunal excepcional, un elemento que más que nada le sirvió para justificar transformaciones organizacionales.

Con el argumento de haberse llenado el vacío institucional de un tribunal superior competente y en vías de rectificarse los malos procederes judiciales, ${ }^{80}$ eliminó el carácter permanente de los jueces o Vocales y redujo el número de miembros permanentes. Además, Valdés, nombrado por Espartero al inicio del período de Regencia, había llegado a La Habana acompañado de su amigo y compañero de armas durante la primera guerra carlista, el entonces General Narciso López, como hombre de confianza, entregándole la Gobernación de Trinidad y la presidencia del Tribunal militar. ${ }^{81}$ Valdés todavía sentía los ecos del descrédito de la Comisión en 1839 y la poca efectividad de las medidas de Ezpeleta en ese sentido, lo que expresó en una carta al Ministerio de la Guerra:

${ }^{79}$ AUTO acordado de la Audiencia Pretorial de La Habana en 24 de febrero de 1840. La Habana: Imprenta del Gobierno, Capitanía General y Real Audiencia Pretorial, 1840. p. 1.

${ }^{80}$ Circular del Capitán General Jerónimo Valdés sobre competencias de la Comisión Militar, ANC. Fondo Comisión Militar, leg. 1 exp. 1.

${ }^{81}$ La participación de Narciso López en la primera guerra carlista bajo las órdenes de Valdés lo había ascendido al grado de Brigadier en 1836, y luego alcanza el de General como Gobernador de Valencia entre 1839 y 1840. Cesó su actuación como Presidente del tribunal militar cubano en 1843, cuando O'Donnell, como sucesor de Valdés luego del pronunciamiento de Narváez, lo remueve. Su participación posterior al frente de los movimientos de anexión de la isla a los estados del sur de los Estados Unidos, entre 1849 y 1851, lo condenaron, en procesos seguidos en la propia Comisión militar, a muerte en garrote vil en septiembre de 1851. 
También encontré defectuosa la organización en que se hallaba constituido el mismo Tribunal teniendo siete vocales permanentes de la clase de Jefes retirados con familia y relaciones en el pais, disfrutando por esta Comisión el sueldo entero de empleados, habiendo dispuesto la supresión de unas plazas que sobre erogar crecidos gastos a la Hacienda militar no podían ser desempeñados con la independencia conveniente a la más imparcial y recta justicia, sustituyéndolas con los Jefes de los Cuerpos de la guarnición y demás que residen en esta Capital a la manera que se verifica en el orden establecido para los Consejos de Guerra. [...] Posteriormente y como consecuencia de las antecedentes providencias he reducido el número de fiscales y secretarios a solo tres de cada clase incorporándose a sus respectivos Cuerpos y quedando en su situación de retirados los demás que desempeñan estos encargos. ${ }^{82}$

Josep Maria Fradera ha apuntado ya los prejuicios de Valdés en relación con las conveniencias políticas y hacia los criollos americanos. ${ }^{83}$ Esto debe vincularse con el interés de férreo ayacucho en el control estricto del panorama político-social ultramarino, ${ }^{84}$ que se demostraría poco después con la puesta en práctica de renovados agentes con funciones esencialmente policiales y subordinados al jefe supremo (los pedáneos), la aprobación de un extenso Bando de Gobernación y Policía de la Isla de Cuba en noviembre de 1842, y en general con la implicación de un mayor número de peninsulares en el gobierno colonial. Su posición en relación con la Comisión encaja en ese marco, sobre todo su interés en el desmantelamiento de las redes clientelares creadas -la colocación al frente del tribunal de su amigo Narciso López le reportaba cuando menos control e identidad de intereses-, y en el afianzamiento de la Capitanía General como poder efectivo. Además, innegablemente, era también consecuencia del cambio en el panorama institucional judicial generado por la aparición de la Audiencia Pretorial.

En cuanto a las competencias del tribunal, en realidad solo lo despojó de los encargos circunstanciales que con los años se le habían

\footnotetext{
${ }^{82}$ ANC. Fondo Comisión Militar, leg. 1 exp. 1.

${ }^{83}$ FRADERA, Josep M. Colonias para después de un imperio. Op. Cit. pp. 255-256.

${ }^{84}$ Jerónimo Valdés fue uno de los generales que impulsaron el cambio liberal y la Regencia de María Cristina. Sobre su proyección de gobierno comenta Fradera: “...Valdés, que tenía una larga carrera política y militar a sus espaldas y una relación privilegiada con Espartero, y que poseía mayor habilidad politica que Tacón, tenía muy pocas dudas sobre la necesidad de establecer con claridad un modelo político derivado del giro de la política colonial en 1837 desde la más importante Capitanía del Ultramar español." Ibidem.
} 
atribuido. Puesta en vigor la circular y aprobada por Madrid en septiembre de 1841, el contenido del artículo primero fue ratificado en los mismos términos en el Bando de Gobernación... del año siguiente: ${ }^{85}$

Solo quedan sujetos al juicio y fallo de la Comisión Militar ejecutiva, los salteadores, ladrones y malhechores en despoblado, siempre que formen cuadrilla y cualesquiera que sean sus aprehensores; los reos de sedición, tumulto u otra tentativa contra los derechos de S.M. la Reina, orden público y sistema legal establecido, y los esclavos que se subleven, cualquiera que sea el pretexto o motivo, excediendo el número de tres los confabulados. ${ }^{86}$

Al final de cuentas se mantenía la ambivalencia de la formulación: "malhechores", "bandidos" y desordenes de naturaleza política -ahora sí nítidamente identificados como subversores del orden públicoconstituían una terminología susceptible de interpretarse de manera flexible y abarcadora. La esclavitud por otra parte seguía siendo el principal trasfondo del sistema de dominio, y la capacidad del mando político de gestionarla -frente a los temores cada vez más fuertes de los hacendados tras las frecuentes sublevaciones ocurridas desde 1838- se mantenía depositada en la actuación de la Comisión. Tanto así que ni siquiera el Bando de Gobernación... del año siguiente -leído en clave de code noir por cierta historiografía- transformó ese resorte, al inhibir la intervención de las autoridades político-judiciales y policiales en el mundo de la esclavitud. ${ }^{87}$

Valdés dejaba claras las reglas del juego en cuanto a qué intereses debía responder la Comisión sobre todas las cosas, pero no podía, ni pretendía, desprenderse de la efectividad represiva del tribunal, sobre todo porque, en definitiva, seguía siendo el mundo colonial de los años 1841-1843 un paisaje dominado por una lógica tradicional donde, eso sí, se imponía con pie firme la autoridad del mando supremo militar.

\footnotetext{
85 Artículo 26 de la Instrucción de Pedáneos anexa al Bando de Valdés.

${ }^{86}$ Circular del Capitán General Jerónimo Valdés sobre competencias de la Comisión Militar, ANC. Fondo Comisión Militar, leg. 1 exp. 1.

${ }^{87}$ Los Tenientes gobernadores, las justicias de primera instancia y los pedáneos no podían entrar en las haciendas. FRADERA, Josep M. Colonias para después de un imperio. Op. Cit. p. 265.
} 
Se le hizo evidente unos meses después cuando tuvo que ampliar una vez más el conocimiento de la Comisión por el alto número de crímenes en la capital, ya que los tribunales ordinarios e incluso la Audiencia pretorial - parangonada como una reorganización efectiva de la administración judicial- no alcanzaban a reprimirlos con la inmediatez necesaria. ${ }^{88}$ La decisión fue comunicada a la Audiencia y demás autoridades judiciales-gubernativas, que no dejaron de mostrar su inconformidad una vez más, así como a los comisarios de barrio y pedáneos de extramuros "haciéndoles la prevención en tal virtud de que remitan a esa Capitanía General los procedimientos de esta clase", con fecha 20 de abril de 1843.

El Capitán General O’Donnell aplicó una política similar en cuanto a la estabilización de la Comisión bajo su estricto control. Muy a inicios de su mando en 1843 se publicó en la imprenta de la Capitanía General con fines a todas luces propagandísticos un caso de persecución y ejecución de una cuadrilla de malhechores, sin especiales trascendencias políticas pero que permitía mostrar la conmutación de fuerzas

${ }^{88}$ Por circular de 18 de abril de 1843 declaró "por ahora" del conocimiento de la Comisión militar las causas sobre robos y asaltos en la capital y sus barrios extramuros. La consulta del Auditor de Guerra aducía los motivos: "Sin embargo, como dicha Superioridad [Audiencia Pretorial], ni fuez alguno pueden separarse de los trámites establecidos para la prosecución de las causas en sus respectivos fueros, ni quepa por lo mismo precipitar el curso de las de una especie determinada, de aquí es que para lograrlo es indispensable una medida excepcional que sujete las causas de que se trata a una tramitación más breve que la ordinaria. [...] está facultado V.E. ilimitadamente para dictar cuantas providencias estime necesarias al orden, seguridad y conservación de esta Isla y por consecuencia puede, si lo cree conveniente, declarar del conocimiento de la Comisión militar ciertos delitos con el laudable fin de impedir su frecuencia, ya por la celeridad del castigo, ya utilizando el saludable terror que comúnmente inspiran los tribunales militares ejecutivos." Consulta del Auditor de Guerra al Capitán General, 18 de abril de 1843. Cinco meses después, en oficio de 13 de septiembre de 1843, Jerónimo Valdés retiró la competencia en los delitos de hurto y asalto a la Comisión militar. ANC. Fondo Comisión Militar, leg. 1, exp. 1. 
al servicio del alto mando, ${ }^{89}$ y sobre todo la celeridad ejecutiva ${ }^{90} \mathrm{y}$ dureza represiva de la Comisión militar, que dictaminó 10 ejecuciones en garrote vil sin derechos de recusación fiscal o apelación ejecutiva al alto mando militar, además de las usuales condenas a presidio en África.

Particularmente la represión esclava fue uno de los encargos que más ocupó al tribunal excepcional durante la década de 1840, hasta culminar con el sangriento episodio de la represión en 1844 de la denominada Conspiración de la Escalera, que puso fin a un clímax densamente tenso sobre el tema de la esclavitud en el occidente cubano. El proceso que llevó a La Escalera fue un cúmulo de circunstancias políticas locales y el aumento de las presiones inglesas, particularmente con la presencia de David Turnbull en la Isla como cónsul británico (1840-1842), resultado de lo cual entre 1838 y 1843 varias sublevaciones fueron ahogadas por el propio ejército y la intervención del tribunal excepcional. Fue con La Escalera que se mostró fehacientemente la capacidad de intervención de la Comisión y sus efectivos recursos, desdoblada en cuanto a personal -solo en Matanzas, el núcleo principal de los levantamientos, la sección actuante de la Comisión empleó 31 fiscales con sus respectivos secretarios en la "investigación" y sustanciación de las causas- ${ }^{91}$ y desde el punto de vista territorial, pues los efectivos se extendieron hacia los pueblos, zonas rurales y haciendas de gran parte de la región occidental de la Isla. Se procedió por actua-

${ }^{89}$ La causa fue seguida contra 30 individuos entre septiembre de 1842 y noviembre de 1843, entre ellos una partida de 13 "bandidos", por el asesinato del Regidor de Villa Clara y otros dos sujetos. En las averiguaciones y persecuciones de los bandidos participaron sobre todo Capitanes de Armas de milicias, de partidas de seguridad pública y comisarios de barrios. REPRESENTACIONES fiscales y otros documentos importantes de la célebre causa seguida por el Tribunal de la Comisión Militar de esta plaza contra los bandidos que asaltaron, robaron dieron muerte a D. Francisco Arencibia.... Habana: Imprenta del Gobierno y Capitanía General, 1843.

${ }^{90}$ Aunque la persecución y averiguaciones se iniciaron desde la fecha del crimen, en realidad no fue hasta 5 meses después, febrero de 1843, que se tuvieron datos ciertos para remitir el proceso a la Comisión, lo que reduce la duración del mismo en el tribunal militar a 9 meses.

${ }^{91}$ COLECGIÓN de los fallos pronunciados por una Sección de la Comisión Militar establecida en la ciudad de Matanzas para conocer de la causa de conspiración de la gente de color. Matanzas: Imprenta del Gobierno, por S.M., y de la Real Marina, 1844. 
ciones sumarísimas contra los esclavos y sus líderes en las plantaciones, como permitía la vigente disposición de Vives para dichos casos, lo que significó en la práctica el fusilamiento y la violenta muerte en "la escalera" durante las pesquisas de cerca de 300 sublevados. ${ }^{92}$ Pero a partir de abril -la Comisión intervino en marzo en los interrogatorios, ${ }^{93}$ inicialmente llevados a cabo por los propietarios de esclavos- los procesos comenzaron a implicar a muchos mestizos libres y algunos blancos, ${ }^{94}$ una expansión del elemento conspirativo que, como muchas veces se ha señalado, tenía visos de invención de una revolución abolicionista y anexionista por parte de O'Donnell y los negreros peninsulares canalizada a través del tribunal actuante para atajar los empujes ingleses y de los diversos grupos sociales reformistas. El saldo fundamental fue, además de las decenas de muertes en suplicio, ejecuciones, deportaciones a perpetuidad y prisión, ${ }^{95}$ la decantación a favor del gobierno colonial de las intensas tensiones esclavistas de esos años, y una garantía de control insular por parte de O’Donnell. ${ }^{96}$ En el episodio se mostró

${ }^{92}$ PAQUETTE, Robert. Sugar Is Made with Blood: The Conspiracy of la Escalera and the Conflict Between Empires Over Slavery in Cuba. Middletown/Connecticut: Wesleyan University Press, 1988. p. 229.

${ }^{93}$ O’Donnell solicitó al entonces Presidente del tribunal, Brigadier Fulgencio Salas, que tomase control de la situación por cualquier medio luego de los alzamientos de enero-febrero de 1844, lo que fue interpretado por el militar en estos términos: "Cuando se trata de la seguridad del país y de un delito de Estado, cualquier medio es legal y permitido si de antemano existe una convicción moral de que ha de producir el resultado que se desea y exige el bien general." GUERRA SÁNCHEZ, Ramiro. Manual de Historia de Cuba. La Habana: Editorial Nacional de Cuba, 1964. p. 437.

${ }^{94}$ AHUMADA GENTURIÓN, José. Memoria histórico-política de la Isla de Cuba, redactada de orden del señor Ministro de Ultramar. [S.1] : [s.f.]. p. 436.

${ }^{95}$ La sección matancera de la Comisión militar procesó a 1836 individuos, divididos en 1232 libres de color, 590 esclavos y 14 blancos. De ellos fueron sentenciados 78 a ejecución, 1165 a prisión, 435 a extrañamiento o deportación a perpetuidad, y 31 a obras públicas. Tomo los datos de: REID-VAZQUEZ, Michele. The Years of the Lash: Free People of Color in Cuba and the Nineteenth Century Atlantic World. Georgia: University of Georgia Press, 2011. p. 199, nota al pie 106. Aunque otras fuentes computan mayor número de implicados y víctimas, por ejemplo, la más citada usualmente PAQUETTE Robert, Op. Cit.

${ }^{96}$ Sobre los conflictos de Valdés y O’Donnell con la política abolicionista inglesa y las presiones de los sectores sociales cubanos, ver FRADERA, Josep M. Colonias para después de un imperio. Op. Cit. pp. 280-292. 
además la connivencia del tribunal con los intereses de dichos grupos esclavistas, dado que varios de los propietarios de esclavos afectados y conocidos por su violencia represiva participaron en la investigación. ${ }^{97}$

Luego del pasaje de La Escalera, la década de 1840 concluyó sin comparables sobresaltos insurreccionales, y la Comisión, afianzada como nunca antes en su papel cruentamente represivo gracias al terror sembrado en 1844, continuó su labor a la sombra del Capitán General, enmarcada en los poco nítidos límites establecidos por la circular de Valdés de 1841. Así lo confirmó O’Donnell en 1847 al comunicar a los Gobernadores y Tenientes gobernadores de la Isla la orden de que se cumpliese con lo establecido en la prevención de Valdés en cuanto a los conocimientos del tribunal excepcional y contra la práctica evasiva de los tribunales ordinarios que originaba "...graves perjuicios a la administración de justicia y a los objetos de política y de seguridad pública que el gobierno de S.M. se propuso al crear el expresado Tribunal."98

\section{Epílogo}

\section{La normalización de la excepcionalidad}

Como ha quedado dicho, entre 1825 y 1851 los Capitanes Generales, desde Vives pasando por Tacón y Ezpeleta hasta O'Donnell, coincidieron en que la garantía de su efectivo control social era la existencia del tribunal de la Comisión militar como recurso sostenido, regular, cotidiano e impostergable, en un contexto sociopolítico catalogado de "excepcional". Incluso todavía en 1851 el Capitán General Gutiérrez de la Concha, quien luego de crear alternativas represivas impulsaría la supresión de la Comisión, la había utilizado para legitimar su poder en el violento aplastamiento de las intentonas anexionistas de Narciso López y otros entre 1849 y 1851. Luego, entre 1851 y su supresión en 1856, el panorama institucional político-judicial y el equipamiento de orden público en la Isla cambiaron en relación con

${ }^{97}$ Ibidem. p. 287.

${ }^{98}$ ANC. Fondo Comisión militar, leg. 1, exp. 1. 
las décadas precedentes y, sobre todo, se implementaron fórmulas "administrativas" conducentes a entregar una imagen de coherencia con las reformas peninsulares. Es en este contexto que Cocha se pronuncia por la desaparición del tribunal especial, cuyas formas, según su análisis, quedaban obsoletas. ${ }^{99}$

Luego de consultar con el Real Acuerdo y mientras esperaba una respuesta positiva de la Corona para la supresión del tribunal, en agosto de 1855 el Capitán General dictó una circular reduciendo sus competencias a los delitos políticos y las sublevaciones esclavas. ${ }^{100} \mathrm{Su}$ fundamentación ante el cuerpo consultivo muestra lo injustificable (por descontextualizado) que le parecía el recurso extraordinario:

"El establecimiento de un tribunal breve en las formas y serio en los fallos, era una medida no solo saludable, sino necesaria. (...) Verdad es que la situación política de la isla, aunque distinta de la que entonces era, no es tal vez más favorable si bien es otra la causa de los peligros que la amenazan. Pero en el terreno de la administración civil y judicial, se han hecho inmensos progresos, (...) los delitos se disminuyen, sino tanto como fuera de desear, lo bastante para que recorran sin temor los caminos solitarios y se circule libremente a cualquier hora del día y de la noche por las calles de la capital, teatro antes de frecuentes robos y muertes. [...] ¿ iHa llegado el caso de suprimir la Comisión militar cuya existencia nos echan en cara nuestros enemigos como prueba de que solo por el tenor y la fuerza se conserva la isla unida

${ }^{99}$ Así argumentaba el asesor del Capitán General: “...es ciertamente un absurdo legal la existencia de esta Comisión militar que hasta en los procedimientos es más lenta que los tribunales ordinarios de esta Isla, no resultando por consecuencia la menor ventaja con la existencia de la Comisión militar, que los enemigos de España y de la Reina suele presentarnos como argumento de que no podemos gobernar legalmente. (...) Pudiera suceder que las circunstancias aconsejaren a la autoridad militar declarar esta Antilla en estado de sitio y en este caso pudiera crearse la Comisión militar que entendiera y conociera de los delitos que la misma autoridad sometiera a su jurisdicción. De este modo se regiría la Antilla como las de las demás provincias de la Península y se pondría en práctica la Real Orden de 7 de agosto de 1854. La preferencia de los Consejos de Guerra que recoge la Ordenanza a las comisiones militares está y a declarada en Real Orden de 29 de septiembre de 1839...” ANC. Fondo Comisión militar, leg. 120, exp. 6. Sobre la aludida demora procesal de la Comisión, el asesor la establece en comparación con la pretendida celeridad de los juicios en primera instancia luego de la reforma judicial insular de 1855.

${ }^{100}$ La circular de 16 de Agosto de 1855 decretaba: "que la Comisión militar reduzca por ahora sus atribuciones al conocimiento y decisión de las causas que se formen por sedición, tumulto, u otra tentativa contra los derechos de S.M. la Reyna, orden público y sistema legal; y por sublevación de esclavos, cualesquiera que sea el pretexto o motivo siempre que exceda de tres el número de los confabulados; debiendo cesar por lo mismo en el conocimiento y decisión de las causas en que hasta aqui entendió por robos y otros delitos cometidos en despoblado y en cuadrilla." Ibidem. 
a la Metrópoli??'101

Ese cuestionamiento de la legitimidad del recurso extraordinario era un asunto entonces a la sazón en los debates legislativos sobre la elaboración de una ley de orden público y la disconformidad entre por un lado gobierno y represión militares y por otro el universo conceptual constitucional. En mayo del propio año 1855 el diputado Gálvez Cañero presentaba una moción para suprimir la recurrencia a los estados de sitio y abogaba por la puesta en vigor de una ley de orden público que inhibiese la participación militar en los gobiernos territoriales ante situaciones de desorden. ${ }^{102}$ Concha, indudablemente al tanto de por dónde transcurrían los debates, cuatro días antes de emitir la Circular en Cuba presentó la propuesta de supresión del tribunal a Madrid, proponiendo su restablecimiento solo "cuando lo requirieran las circunstancias de la isla." Lo más significativo de su comunicación al Ministerio de Gobernación fue la insistencia en "...la conveniencia de la formación de una ley de orden público en que se establezcan las facultades de la autoridad militar en los casos extraordinarios y sus relaciones con las civiles sobre la

${ }^{101}$ Consulta del Capitán General al Real Acuerdo sobre la conveniencia de suprimir la Comisión militar, 8 de junio de 1855. Ibidem.

102 "Yo no quiero privar al Gobierno de los medios indispensables para atacary destruir los enemigos de las instituciones. ¿Pero no hay diferencia entre este caso y el de una ley que confiera a la autoridad militar el ejercicio de la potestad judicial en todas las causas, por ejemplo, de conspiración? Indudablemente que sí. $Y$ esta doctrina no es nueva, porque la consagra también la ley de 17 de Abril, llamada marcial, ley que no peca de lenidad, y que sin embargo no da a la jurisdicción militar el conocimiento do los casos de conspiración, sino únicamente cuando hay resistencia, que la misma ley califica previniendo las formalidades que deben observarse; pero en los demás casos entiende solo la jurisdicción ordinaria, con exclusión de cualquiera otra y con prohibición de suscitar competencia. Yo concibo la jurisdicción militar en funciones de guerra, cuando hay choque, cuando hay esa resistencia de que habla la ley de 17 de Abril; pero no la concibo, y por lo mismo quiero evitar que ese principio se generalice, en todos los demás casos." DIARIO de Sesiones de las Cortes Generales y Extraordinarias. Madrid: 1870. 9 volúmenes. p. 4861, Sesión de 17 de mayo de 1855. Aunque su moción no prosperó en 1855, la adición presentada se retomaría luego en los debates sobre el artículo 31 de la Constitución de 1869. En definitiva, no es hasta el Sexenio que los progresistas imponen un régimen de legalidad en relación con el estado de excepción. CRUZ VILLALÓn, Pedro. Op. Cit. p. 320. 
base de disposiciones recientemente adoptadas en la Peninsula", ${ }^{103}$ ofreciéndose él mismo para elaborar un proyecto que contemplase las especiales circunstancias coloniales.

La respuesta no tardó en llegar. El 5 de enero de 1856 se decretaba la real orden que disponía la supresión de la Comisión militar y la autorización para que, a juicio del Capitán General (consultando previamente al Real Acuerdo), fuera restablecida solo en casos extraordinarios para conocer de los delitos "que atenten a la seguridad e integridad de la Isla", y con orden de cesar inmediatamente después de desaparecidas las circunstancias que lo motivaren. Las causas que se procesaban en la Comisión pasaron a los juzgados respectivos de los Alcaldes mayores en los diferentes distritos, según circular de 28 de abril de 1856.

Más allá de su cuestionada legitimidad a esta altura del siglo, lo cierto es que el experimento de un tribunal excepcional permanente y ejecutivo rindió frutos. Gracias a él, la regularización de la excepcionalidad, del gobierno de las islas como en estado de sitio ("estado de guerra" en la formalización española del término), fue ordinaria, en el sentido de cotidiana, normalizada y sostenida durante toda la primera mitad del siglo XIX. Luego fue evidente que el experimento represivo desarrollado en Cuba podía ser útil del otro lado del Atlántico: el principio de excepcionalidad revistió carácter constitucional luego de 1869, y a partir de entonces, y sobre todo con la Constitución de 1876, la legislación sobre los estados de guerra, sobre la suspensión de garantías y sobre la aplicación de consejos de guerra, representaría una posibilidad de normalización de la experiencia ultramarina. ${ }^{104} \mathrm{El}$ llamado sistema de "doble ley" surgido en esos años era resultado de

${ }^{103}$ Carta del Capitán General José Gutiérrez de la Concha al Ministerio de Gobernación, 12 de agosto de 1855. ANC. Fondo Comisión militar, leg. 120, exp. 6.

104 "El inicial objetivo de constitucionalización y legalización ha resultado gubernamentalización, finalmente: es el anuncio de una involución que conduciría a la Ley de furisdicciones y, a no tardar, a la dictadura militar" ya que se dejaba la declaración de los estados de excepción en manos de militares locales. "(...) [L] a consecuencia será que las autoridades militares consideren, naturalmente, la vigilancia sobre el estado de la tranquilidad pública como competencia propia", como sucedía en Cuba. CRUZ VILLALÓN, Pedro. Op. Cit. p. 438. 
una mezcla de "normalidad" y "excepción", que no podía descansar en los derechos como principio primero sino en la seguridad. Pero esto merece un análisis aparte.

\section{Bibliografía}

ALONSO ROMERO, María Paz. Cuba en la España liberal (1837-1898). Madrid: Centro de Estudios Políticos y Constitucionales, 2002.

BARCIA ZEQUEIRA, María del Carmen. Élites y grupos de presión. Cuba, 1868-1898. La Habana: Ediciones Ciencias Sociales, 1998.

BARRETO DE SOUZA, Adriana; MOREIRA DOMINGUES DA SILVA Angela. A organização da justiça militar no Brasil: Império e República. Revista Estudos Históricos, vol. 29, no 58, 14 julio 2016, pp. 361-380.

GRUZ VILLALÓN, Pedro. El estado de sitio y la Constitución. La constitucionalización de la protección extraordinaria del Estado (1789-1878). Madrid: Centro de Estudios Constitucionales, 1980.

FERNÁNDEZ GAYUELA, José G. Relación colonial y élite hispano-cubana en la España del XIX. Salamanca: Ediciones Universidad de Salamanca, Stud. hist. $\mathrm{H}^{\mathrm{a}}$. Cont., 15, p. 21-34.

FRADERA, Josep M. Colonias para después de un imperio. Barcelona: Ediciones Balleterra, S.L., 2005.

De la periferia al centro. (Cuba, Puerto Rico y Filipinas en la crisis del Imperio español). Anuario de Estudios Americanos, vol. 61, no 1, 30 Juin 2004, pp. 161-199.

. La Nación Imperial (1750-1918), Barcelona: Edhasa, 2015. V. II.

GARRIGA ACOSTA, Carlos. Patrias criollas, plazas militares: sobre la América de Carlos IV. Horizontes y Convergencias. Lecturas Históricas y Antropológicas sobre el Derecho, 2009.

KUETHE, Allan J. Cuba 1753-1815, Crown, Military and Society. Knoxville: The University of Tennessee Press, 1986.

LACCHÉ, Luigi. Ordo non servatus. Anomalie processuali, giustizia militare e specialia in Antico Regime. Studi Storici, 29-2, 1988, pp. 361-384.

LORENTE SARIÑENA, Marta y MARTÍNEZ PÉREZ, Fernando. Orden público y control del territorio en España (1822-1845): de la Superintendecia general de policía a la Guardia civil, Revista jurídica Universidad 
Autónoma de Madrid, no 19, 2009, pp. 195-210.

LLAVERÍAS, Joaquín. La Comisión militar ejecutiva y permanente de la Isla de Cuba. Academia de Historia de Cuba. La Habana: Imprenta El Siglo XX, 1929.

MANTECÓN, Tomás. Formas del disciplinamiento social, perspectivas históricas. Revista de Historia Social y de las Mentalidades, vol. 2 (14). p. 265-298.

MECGARELLI, Massimo. Paradigmi dell'eccezione nella parabola della modernità penale. Una prospettiva storico-giuridica. Quaderni storici, no 2, 2009, pp. 493-522.

MELON JIMÉNEZ, Miguel Ángel. Una cuestión de Estado. La persecución del contrabando durante los reinados de Carlos III y Carlos IV. Mélanges de la Casa de Velázquez, 39-2, 2009, pp. 83-103.

MOLINA, Eugenia. Tras la construcción del orden provincial: las comisiones militares de justicia en Mendoza, 1831 y 1852. In: BARRIERA, Darío G. (org.), La Justicia y las formas de la autoridad. El Río de la Plata (Siglos XVII a XIX). Rosario: Red Columnaria/ISHIR/CONICET, 2010, pp. 83-105.

PAQUETTE, Robert. Sugar Is Made with Blood: The Conspiracy of la Escalera and the Conflict Between Empires Over Slavery in Cuba. Middletown/Connecticut: Wesleyan University Press, 1988.

PIAZZI Carolina A. Administración y materialidad: una etnografía del Juzgado del Crimen del Rosario (Argentina, segunda mitad del siglo XIX). Historia Crítica, no 63, 2017, pp. 53-74.

REID-VAZQUEZ, Michele. The Years of the Lash: Free People of Color in Cuba and the Nineteenth Century Atlantic World. Georgia: University of Georgia Press, 2011.

RISQUES CORBEILLA, Manel. La militarización del control político sobre el territorio. Barcelona, Gobierno civil y orden público en la primera mitad del siglo XIX. (2014, Inédito).

VILLACAÑAS BERLANGA, José Luis. Historia del poder político en Es- 
paña. Barcelona: R.B.A. Libros, S.A., 2014.

\section{Fuentes impresas consultadas:}

AHUMADA CENTURIÓN, José. Memoria histórico-política de la Isla de Cuba, redactada de orden del señor Ministro de Ultramar. [S.l] : [s.f.].

AUTO acordado de la Audiencia Pretorial de La Habana en 24 de febrero de 1840. La Habana: Imprenta del Gobierno, Capitanía General y Real Audiencia Pretorial, 1840.

APÉNDICE de la Relación del gobierno superior y Capitanía General de Miguel Tacón. La Habana: Imprenta del gobierno y capitanía general, 1838.

CALVO, José María. Representación dirigida a S.M. la Reina Gobernadora sobre reformas en la Administración de justicia en la Isla de Cuba, en 25 de noviembre de 1834, Madrid: Imprenta de Don Lázaro Fernández de Angulo, 1835.

GARAVANTES, José Vicente. Tratado de los procedimientos en los Juzgados militares. Madrid: Imprenta y librería de Gaspar y Roig, editores, 1853.

GOLECGIÓN de los fallos pronunciados por una Sección de la Comisión Militar establecida en la ciudad de Matanzas para conocer de la causa de conspiración de la gente de color. Matanzas: Imprenta del Gobierno, por S.M., y de la Real Marina, 1844 .

DECRETO de Valencia. Madrid: Gaceta Extraordinaria de Madrid del Jueves 12 de Mayo de 1814. Agencia Estatal Boletín Oficial del Estado (BOE). Referencia BOE-A-1814-282. Disponible en: Http://www.boe. es/datos/pdfs/BOE//1814/070/A00515-00521.pdf Acceso en: 5 de enero de 2017.

DIARIO de Sesiones de las Cortes Generales y Extraordinarias. Madrid: 1870.9 volúmenes.

ORDENANZAS de S.M. para el régimen disciplinario de sus ejércitos. 1768. Madrid: en la Imprenta Real, 1815. 3 tomos.

PINCELADA primera para el gobierno sombrío de las iniquidades cometidas por el asesor titular de la Comisión militar ejecutiva permanente establecida en la ciudad de La Habana, don José Ildefonso Suárez, por don Cristóbal Zurita y don Antonio Sánchez, fiscales que han sido de ella, y por otros notables personajes... La Habana: Imprenta de Luque, 1841.

REPRESENTACIONES fiscales y otros documentos importantes de la cé- 
lebre causa seguida por el Tribunal de la Comisión Militar de esta plaza contra los bandidos que asaltaron, robaron dieron muerte a D. Francisco Arencibia.... Habana: Imprenta del Gobierno y Capitanía General, 1843.

\section{Archivos Consultados:}

Archivo de Indias (AGI). Fondo: Indiferente.

Archivo Nacional de Cuba (ANG). Fondos: Comisión Militar; Gobierno Superior Civil; Reales Ordenes y Cédulas; Miscelánea de Libros, Miscelánea de Expedientes.

Museo Histórico de la Oficina del Historiador. La Habana, Cuba. ACTAS Capitulares del Ayuntamiento de La Habana.

\section{Tabla \# 1}

\section{Penas impuestas en la \\ Comisión militar entre 1825 y 1836 \\ Elaboración propia.}

\begin{tabular}{|c|c|}
\hline \multicolumn{2}{|c|}{ Penas impuestas en la Comisión militar entre 1825 y $\mathbf{1 8 3 6}^{1}$} \\
\hline Delito & Penas \\
\hline Asesinato & $\begin{array}{l}\text { Pena capital: garrote vil u hor- } \\
\text { ca } \\
10 \text { años de presidio en África }\end{array}$ \\
\hline $\begin{array}{l}\text { Sublevación, levantamiento de esclavos y/o ase- } \\
\text { sinatos cometidos por ellos }\end{array}$ & $\begin{array}{l}\text { Pena capital: fusilamiento, } \\
\text { horca o garrote vil con suplicio } \\
6 \text { - } 8 \text { - } 10 \text { años de presidio en } \\
\text { África } \\
8 \text {-10 años de trabajos penosos } \\
\text { con grillete en las haciendas }\end{array}$ \\
\hline
\end{tabular}




\begin{tabular}{|c|c|}
\hline Bandolerismo, salteadores de caminos & $\begin{array}{l}8 \text { - } 10 \text { años de presidio en Áfri- } \\
\text { ca } \\
\text { Menos usual: horca; } 4 \text { - } 8 \text { años } \\
\text { de servicio de armas fuera de } \\
\text { la Isla }\end{array}$ \\
\hline Robo y uso de armas prohibidas & 6- 8 años de presidio en África \\
\hline Complicidad con bandidos, receptores, etc. & $\begin{array}{c}6 \text { meses }-1-2-4 \text { años de } \\
\text { obras públicas }\end{array}$ \\
\hline $\begin{array}{l}\text { Asalto y/o robo, en poblado o en despoblado } \\
\text { (puede tener agravantes como heridas infringi- } \\
\text { das o asesinatos) }\end{array}$ & $\begin{array}{c}\text { 4-6 - } 8 \text { - } 10 \text { años de presidio } \\
\text { en África o en Cuba } \\
1-2-4-6 \text { años de obras } \\
\text { públicas } \\
\text { Puede acompañarse de } 50- \\
100-200 \text { azotes }\end{array}$ \\
\hline Alborotos, asonadas o desórdenes públicos & $\begin{array}{c}\text { Prisión } \\
\text { Servicio de armas } \\
\end{array}$ \\
\hline Papeles y/o palabras subversivas & $\begin{array}{l}\text { 2- } 6 \text { - } 8 \text { años de destierro o de- } \\
\text { portación } \\
4 \text { - } 6 \text { - } 8 \text { - } 10 \text { años de presidio } \\
\text { en África o Cuba } \\
2 \text { - } 4 \text { años de obras públicas } \\
\text { Menos usual: extrañamiento } \\
\text { perpetuo }\end{array}$ \\
\hline Emisarios y traidores & Pena capital con suplicio \\
\hline Espionaje & Extrañamiento \\
\hline Conspiración & $\begin{array}{c}\text { Pena capital } \\
\text { Extrañamiento o destierro a la } \\
\text { Península } \\
6-8 \text { - } 10 \text { años de presidio en } \\
\text { África o Cuba } \\
4 \text { - } 6 \text { años de obras públicas } \\
6 \text { meses - } 1 \text { año de prisión } \\
\text { Incautación de bienes }{ }^{2}\end{array}$ \\
\hline Carlismo o absolutismo & $\begin{array}{c}6 \text { años de presidio en Cuba o } \\
\text { en África }\end{array}$ \\
\hline
\end{tabular}

(Footnotes)

1 La síntesis comprende 162 procesos correspondientes a este período.

2 Fue común que se decretase la incautación de bienes de los procesados. Luego por R.O de 2 de noviembre de 1849 se dictaminó que la gratificación del Presidente y los gastos de los fiscales y 
secretarios fueran satisfechos con el producto de los caudales de los sentenciados, lo que hizo más frecuente la medida. La medida aparece recogida en: LLAVERÍAS, Joaquín. La Comisión militar ejecutiva y permanente de la Isla de Cuba. Academia de Historia de Cuba. La Habana: Imprenta El Siglo XX, 1929, p. 18.

Recebido: 05/07/2018 - Aprovado: 25/12/2018 